\title{
Antarctic iceberg distribution and dissolution from ship-based observations
}

\author{
Tim H. JACKA, ${ }^{1}$ A. Barry GILES ${ }^{2}$ \\ ${ }^{1}$ Department of the Environment and Heritage, Australian Antarctic Division and Antarctic Climate \\ and Ecosystems CRC, Private Bag 80, Hobart, Tasmania 7001, Australia \\ E-mail: jglac@bigpond.com \\ ${ }^{2}$ Spurion Technology Pty Ltd and Antarctic Climate and Ecosystems CRC, Private Bag 80, Hobart,
} Tasmania 7001, Australia

\begin{abstract}
The Australian Antarctic Program's iceberg dataset (from ship-based observations), including information from the austral summer seasons $1984 / 85$ to $1999 / 2000$, is examined and used to extend earlier studies. Using 'snapshots' of the iceberg population to provide an idea of the iceberg life cycle, the distribution of icebergs between 60 and $150^{\circ} \mathrm{E}$ is discussed in terms of calving regions and ocean currents. Temporal changes are also examined. The discussion leads us to the point where we can define an area, bounded to the north by the maximum sea-ice limit and to the south by the Antarctic Divergence, in which icebergs are confined as they drift eastward. This allows estimation of total dissolution, in terms of iceberg numbers and volume, within $10^{\circ}$ longitudinal sectors and, with knowledge of drift speeds, iceberg movement rates and freshwater input across the sector. Iceberg dissolution rates are found to be $\sim 0.03-0.05 \mathrm{~m} \mathrm{~d}^{-1}$ and the total mass contribution of fresh water to the ocean as the icebergs traverse our $30^{\circ}$ of longitude study sector is $\sim 32 \mathrm{Gt}$. This amounts to a contribution equivalent to precipitation of $\sim 15.5 \mathrm{~cm} \mathrm{a}^{-1}$, accounting for $\sim 2 \%$ of the total iceberg discharge from the Antarctic ice sheet.
\end{abstract}

\section{INTRODUCTION}

An upsurge of interest two to three decades ago in the distribution, dissolution and physical characteristics of icebergs was prompted primarily by a perceived possibility that Antarctic icebergs might be utilized as a freshwater source suitable to quench the thirst of large cities. Following a series of conferences (Husseiny, 1978; Russell, 1979; Annals of Glaciology, vol. 1, 1980), the rise and fall of a small informal but informative journal (Iceberg Research, 1982-91, published by the Scott Polar Research Institute, Cambridge, UK) and several landmark publications (e.g. Weeks and Campbell, 1973; Schwerdtfeger, 1979; Robe, 1980), the consensus was that icebergs might, for a cost comparable with desalination, be diverted as they drifted in the known ocean currents, to a Southern Hemisphere location where they might be utilized. There, the utilization of the icebergs poses problems perhaps greater than the initial harvesting (Lawson and Russell-Head, 1983).

In recent years several large icebergs have broken away from the Antarctic continent (e.g. Lazzara and others, 1999). We have seen the partial collapse of the Larsen Ice Shelf (Rott and others, 1996, 1998, 2002), realized that as much as $20-30 \%$ of the ice discharge from the Antarctic continent may be in the form of basal meltwater (Jacobs and others, 1996) and found new evidence of ice-sheet thinning in the Pine Island and Thwaites Glacier drainage basins (Wingham and others, 1998; Rignot, 2001; Zwally and others, 2002). Thus, there are now further reasons to examine iceberg distribution and dissolution rates: (1) as an indicator of melt or freeze rates at the underside of the polar ice shelves given a warmer atmosphere and ocean than exists at present, i.e. iceberg studies can be treated as calibration experiments of how ice shelves may react to further climate change, (2) to better understand abrupt climate-change mechanisms (Heinrich events) (Hemming, 2004) in which iceberg calving and associated freshwater flux are essential elements, (3) for comparison with Antarctic mass budget so that estimates might be made of the ratio of iceberg discharge to melt from the continent (e.g. Orheim, 1985) and (4) as a tool for a better understanding of the freshwater input and physical oceanography of the Southern Ocean (the movement of icebergs is an indicator of ocean currents). One inexpensive method of estimating the iceberg dissolution rate is by statistical analysis of large datasets collected over many years from Antarctic research and station resupply vessels.

Using the Australian Antarctic Program (AAP) iceberg dataset, Hamley and Budd (1986) extended the work of Budd and others (1980). They examined the concentration and size distribution of icebergs in the Australian sector of the Southern Ocean to infer iceberg median life and dissolution rates. Hamley and Budd found a median life for icebergs $<1000 \mathrm{~m}$ wide, before major breakage, to be about 0.2 years. This estimate, they suggested, applies to icebergs within the Circumpolar Current and may not be applicable to coastal icebergs in cold slow-moving water. They estimated a dissolution rate for a mean water temperature of $+1^{\circ} \mathrm{C}$, of $0.12 \mathrm{~m} \mathrm{~d}^{-1}$. Budd and others (1980) had 1 year (1977/78) of rigorously collected data at their disposal. Hamley and Budd (1986) had 6 years (1978/79-1983/84) of data available. We now have a further 16 years (1984/85-1999/2000) of data. In this paper, we build on the previous work. The paper is modelled on the Hamley and Budd approach (using similar data plots, although we now consider the data in terms of volume as well as concentration), and uses the additional 16 years of data to refine the descriptions of the size distribution, and to re-evaluate the rate of dissolution of icebergs in the Southern Ocean. 


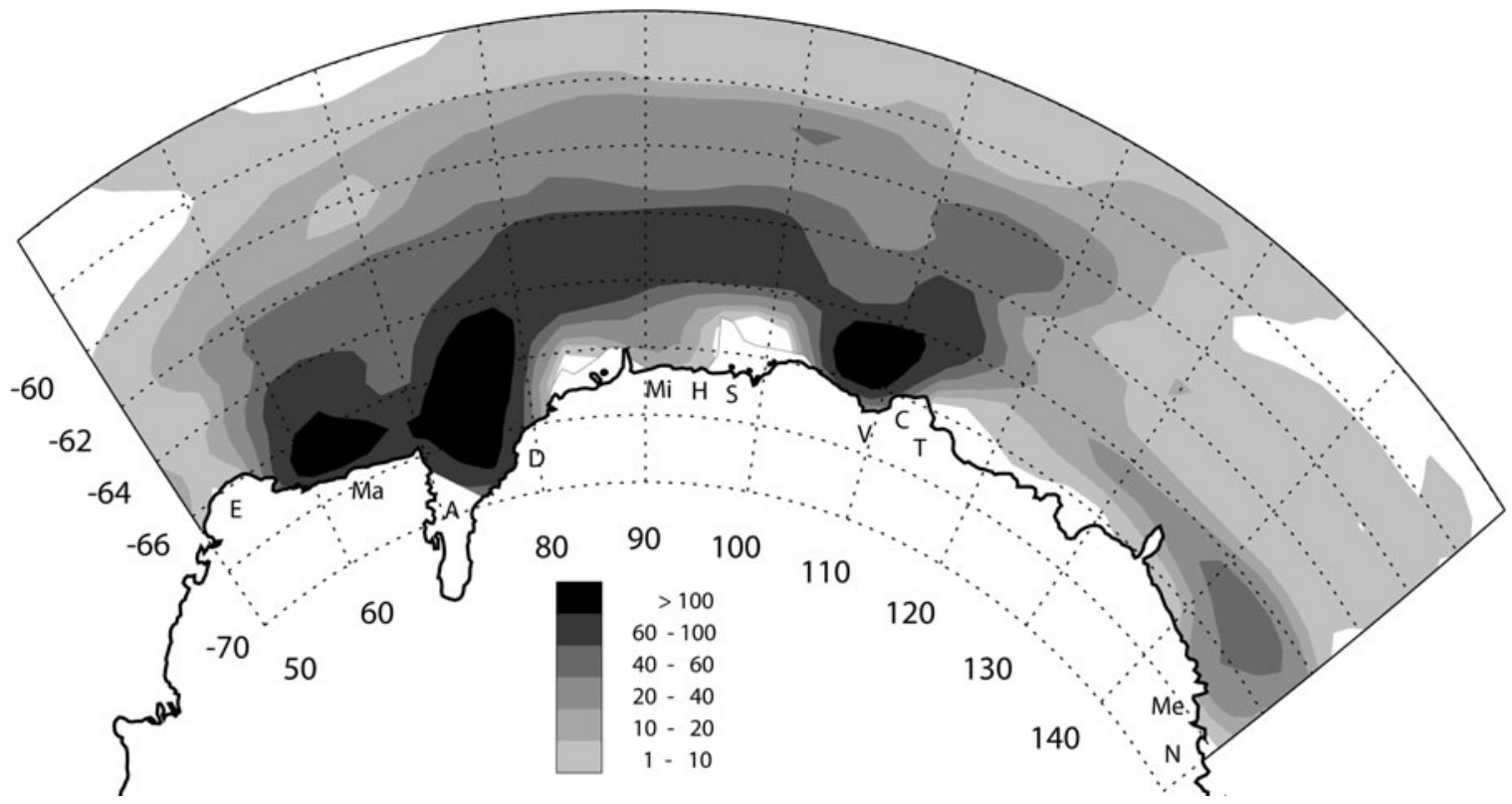

Fig. 1. Map showing distribution of the total number of iceberg observations from AAP voyages, for the period 1984/85-1999/2000. Locations marked from west to east along the Antarctic coast are E - Enderby Land, Ma - Mawson, A - Amery Ice Shelf, D - Davis, Mi - Mirny, H - Helen Glacier, S - Shackleton Ice Shelf, V - Vanderford Glacier, C - Casey, T - Totten Glacier, Me - Mertz Glacier and $\mathrm{N}$ - Ninnis Glacier.

\section{ICEBERG DATA COLLECTION}

The AAP has routinely collected iceberg distribution and size data since its first expeditions south in 1948. Observations were often qualitative, however, and in 1977 a more rigorous quantitative data collection routine was initiated. Data collected included (1) iceberg number concentration within a $28 \mathrm{~km}$ (15.1 mi (int., naut.)) radius (using ship's radar), (2) maximum visible horizontal dimension at the waterline, referred to as 'width', classed into one of five categories (when possible using sextant and radar), (3) for tabular icebergs, height above the waterline (using sextant and radar), (4) photographs to determine shape, (5) sea-ice concentration, (6) ocean temperature and (7) ship's latitude and longitude. The five width categories were 10-50, 50-200, 200-500, 500-1000 and $>1000 \mathrm{~m}$. Budd and others (1980) carried out the most comprehensive (to that date) examination of iceberg concentration and size distributions, using the 1977/78 data.

The AAP was not alone in routinely collecting ship-based iceberg observations (e.g. Orheim, 1980). In 1982/83, guidelines established by the Scientific Committee on Antarctic Research (SCAR) Working Group on Glaciology for collecting and archiving these data were adopted. The SCAR iceberg project is coordinated by Norsk Polarinstitutt (Orheim, 1985; personal communication from O. Orheim, 2003). As of 2003 it had accumulated data on more than 234000 icebergs, of which $80 \%$ have been classified by size. The data are being prepared for presentation on the World Wide Web (at http://www.npolar.no). More recently, the US National Ice Center (NIC) has made available (at http://www.natice.noaa.gov) a collection of observations, commencing in 1979, of icebergs $>10 \mathrm{mi}$ (int., naut.) $(18.53 \mathrm{~km})$ long (also see Long and others, 2002).

Since 1982/83 all Australian data have been made available to the Norsk Polarinstitutt collection. This involved a change in the observation radius to $12 \mathrm{mi}$ (int., naut.)
(22.2 km). Starting with the $1984 / 85$ austral summer season, the observation radius for the Australian data was further reduced to $6 \mathrm{mi}$ (int., naut.) $(11.1 \mathrm{~km})$. It was apparent (Wadhams, 1988; Allison and Musil, 1989; Musil, 1999) that small icebergs are difficult to measure with any accuracy at long range, the number may have previously been underestimated, and size estimates for icebergs less than $50 \mathrm{~m}$ were particularly unreliable. The height of the bridge of the ships used is such that distance to the horizon is a reasonable estimate of $6 \mathrm{mi}$ (int., naut.) $(11.1 \mathrm{~km})$. The width categories were also changed (and the number increased) to 25-100, 100-200, 200-400, 400-800, 800-1600, 16003200 and $>3200 \mathrm{~m}$. Hamley and Budd (1986) suggested that size groupings that exactly doubled in size with each step would help refine the estimates of iceberg dissolution rates. In hindsight, this change was probably not wise since it rendered the Australian data incompatible for direct comparison with the rest of the data in the Norsk Polarinstitutt collection. Interpolation from one scheme to another, however, is not difficult.

The area covered by the Australian iceberg dataset extends from 50 to $150^{\circ} \mathrm{E}$ and from the Antarctic coast to as far north as the most northerly sightings. The frequency of observations at any one location within the area is extremely variable and is determined by the logistical priorities each operational season. Figure 1 is a map of the area, showing the distribution of observations for the period 1984/851999/2000. A clear feature of the map is the concentration of observations along the broad shipping lane between the three Australian stations, Mawson, Davis and Casey, and from Casey to the northeast, the direction of Hobart. Note the absence of observations in one small coastal area $\left(\sim 112-130^{\circ} \mathrm{E}\right)$ where, for operational reasons or because sea ice has prevented it, ships have not visited. There is a concentration of observations in the region north of Mertz Glacier $\left(140-150^{\circ} \mathrm{E}\right)$, the location of some major sea-ice and oceanographic research projects. Other than this, the 
number of observations west of $60^{\circ} \mathrm{E}$ and east of $130^{\circ} \mathrm{E}$ is too small for us to draw strong conclusions and we therefore usually restrict the discussion to the area between 60 and $130^{\circ} \mathrm{E}$. Within this area, the concentration of observations is sufficient everywhere south of $\sim 60^{\circ} \mathrm{S}$ to draw some meaningful conclusions.

This dataset, consisting of all iceberg data collected on AAP voyages between, and including, the austral summer seasons 1978/79 and 2000/01, is one of the most complete and long-term collections of such data. It is available on the World Wide Web at the Antarctic Climate and Ecosystems CRC site (http://staff.acecrc.org.au/ jacka/ climate).

\section{DATA EDITING AND QUALITY}

We have carried out a detailed scrutiny of the entire Australian iceberg dataset, and it is the corrected dataset that appears on the above website. The records have been logged by a large number of observers on many ships. The observers exhibit varying degrees of training and attention to detail. Errors can be made for many reasons, ranging from simple typographical errors to faulty equipment giving erroneous values.

Checking of data can often be done line by line. Sometimes however, whole sections of data need to be examined to spot 'the odd one out'. We cannot claim the dataset is now perfect, but we have removed the worst errors and inconsistencies. The accuracy of the observations is spatially and temporally variable, and impossible to determine. Since we are often dealing with relatively low numbers of observations at any particular location, the data are usually co-added over a substantial range of latitude and longitude so any remaining positional errors will be of little significance. We now have a total of 7186 observations of 60749 icebergs, covering a period of $\sim 20$ years, and we can have greater confidence in these results than we did 20 years ago (cf. Hamley and Budd, 1986). The following data quality categories were checked:

\section{Zero $(0)$ versus capital letter $(\mathrm{O})$}

A surprisingly large number of data in the initial log had the character value $\mathrm{O}$ (capital letter $\mathrm{O}$ ) rather than 0 (zero). This is very difficult to visually spot on a simple file listing but becomes obvious when trying to read and use the numerical values. All incorrectly typed Os were replaced with 0 before any other corrections.

\section{Dates and times}

Occasionally, examples were found in which the date was clearly entered incorrectly immediately after midnight. These examples were corrected. Sometimes the time values went 'backwards' due to simple typographical errors that were easily detected. A few examples occurred where, for short sequences of observations, a 24 hour system was clearly not followed. All these timing problems were tracked down and corrected.

\section{Latitude and longitude}

At times it has been required that data be entered in the form 'dd.mm' for latitude and 'ddd. $\mathrm{mm}^{\prime}$ for longitude. Clearly this sometimes caused confusion for some observers since some ' $\mathrm{mm}$ ' (minutes of arc) values were in the range
60-99. All values greater than or equal to 0.60 were multiplied by 0.6 .

\section{Sea temperature}

Near-surface sea-water temperature is measured with a thermometer mounted in an intake at the bow of the ships. Prior to 1990, most temperature measurements were carried out in a sampling bucket thrown over the side of the ship then drawn aboard by a rope. Logged water temperatures were checked by examining the sea-ice concentration value. All temperatures were restricted to the range -2.0 to $+5.0^{\circ} \mathrm{C}$. If any sea ice was present, sea-water temperatures in the range -1.7 to $-1.8^{\circ} \mathrm{C}$ were considered acceptable. Any temperature that did not conform to these constraints was set to 'no observation'. One exception was permitted. If sea ice was present and the water temperature was recorded in the range +1.7 to $+1.8^{\circ} \mathrm{C}$ these values were changed to negative values.

\section{Iceberg size distribution}

There are eight iceberg counts within each observation. The first count is the total number of icebergs observed, while the other seven are the counts for each size distribution. Note the size distribution categories changed and the number of classes reduced by two between the $1983 / 84$ and 1984/85 seasons. Counts of the two largest size classes were set to zero for the data prior to the change. On some occasions, the total count has been recorded although there is no size distribution assignment. In this case, the total has been left as recorded. The sum of the size distribution counts should equal the total count, but often this was not the case. When size distribution counts were recorded but failed to sum to the recorded total, the total was changed to always equal the sum of the distribution counts. This problem ceases for data after 1995; since then data have been entered directly into a laptop computer, as prompted by software. The software asks the operator to re-enter size data if totals are incompatible with the individual counts.

\section{Ship speed}

Each pair of iceberg observations (i.e. including position and time) enables the ship's speed to be calculated. Although the positional change is often small, speed was calculated using spherical trigonometry. None of the ships used was capable of significantly more than 15 knots $\left(28 \mathrm{~km} \mathrm{~h}^{-1}\right)$ but the uncorrected data revealed many instances of substantially higher apparent speeds. Often the position change or time difference was small. Small errors can then produce anomalous speeds. In particular, the ship's position was not accurately recorded prior to the advent of the global positioning system (GPS), and some jumps in the 'dead reckoning' from the navigator's log can be expected. We managed to patch up values causing extremely high velocities (e.g. $>100$ knots) by examining short plots of latitude and longitude against time. However, there still remain many examples of ship speeds substantially greater than 15 knots. These are not confined to the pre-GPS era, although there are more in the earlier years. There are no grounds for further editing these anomalies since we usually do not know which parameter is in error. We assume for the spatial scales on which these data will be utilized that the implied position and/or timing errors will not be significant. 


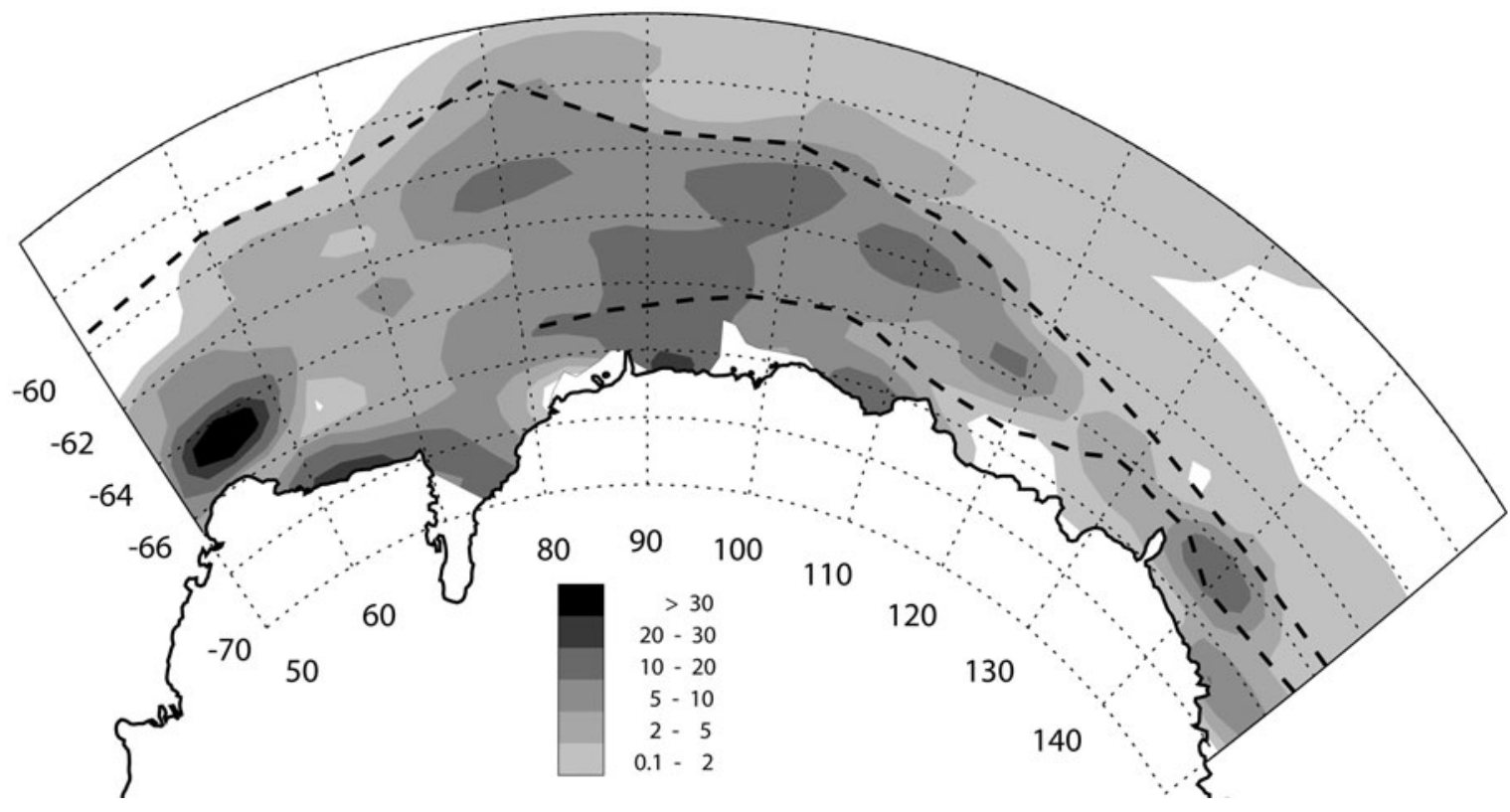

Fig. 2. Map showing contours of iceberg concentration (total number of icebergs sighted within $6 \mathrm{mi}$ (int., naut.) (11.1 km) radius of the ship, divided by the number of observations) for the period 1984/85-1999/2000. The more northern dashed curve is the northern extent of the mean maximum sea-ice extent (after Jacka, 1983). The southern dashed curve is transcribed from Figure 3.

\section{SPATIAL DISTRIBUTION}

Figure 2 is a map of iceberg concentration (the number of icebergs sighted within $6 \mathrm{mi}$ (int., naut.) $(11.1 \mathrm{~km})$ of the ship, divided by the number of observations) for the area covered by the data, over the 16 year period of the study (1984/85-1999/2000). It is evident that higher concentrations of icebergs are found adjacent to coastal locations of high glacial discharge (e.g. the Amery Ice Shelf $\left(70-80^{\circ} \mathrm{E}\right)$, Helen Glacier and Shackleton Ice Shelf $\left(90-95^{\circ} \mathrm{E}\right)$, Vanderford Glacier $\left(105-110^{\circ} \mathrm{E}\right)$ and Ninnis and Mertz Glaciers $\left.\left(140-150^{\circ} \mathrm{E}\right)\right)$. There are also some areas where iceberg concentrations close to the coast are high because they are grounded in areas where the east wind drift forces them into relatively shallow water (e.g. off Enderby Land $\left(50-60^{\circ} \mathrm{E}\right)$ and off the Mawson coast $\left(60-70^{\circ} \mathrm{E}\right)$ ).

In the deeper water away from the coast, the pattern of iceberg distribution is more interesting and more important for interpretation in terms of dissolution rates. First, note the more northerly dashed curve in Figure 2 indicates the mean (over 10 years) northern edge of the sea ice at maximum extent (Jacka, 1983). Maximum sea-ice extent occurs in September to mid-October. This curve closely envelops the northern extent of the higher iceberg concentrations, observed primarily during the austral summer. Higher temperatures and the distribution of ocean currents would seem to be the major controls on the northern extent of both sea ice and icebergs.

The pattern of iceberg distribution suggests that icebergs generated by the Amery Ice Shelf initially drift slightly northeast (compare a transect in Figure 2 along longitude $70^{\circ} \mathrm{S}$ with another along $80^{\circ} \mathrm{S}$ ). Icebergs generated by the Shackleton Ice Shelf seem to drift due north from the Mirny coast, and icebergs generated by Vanderford Glacier drift northwest. There are low concentrations of icebergs north of Vanderford Glacier; note, however, that the apparently lowconcentration area near the coast at $\sim 115-120^{\circ} \mathrm{E}$ is because there are very few data here. The result of these drift directions from the coast is that there are high iceberg concentrations north of $64^{\circ} \mathrm{S}$ at longitude $85-95^{\circ} \mathrm{E}$. In this area, the icebergs are caught in the west-to-east flowing Circumpolar Current. Thus there are elevated concentrations evident as far north as the maximum sea-ice extent limit, and to the east as far as $140^{\circ} \mathrm{E}$.

Earlier work by Tchernia and Jeannin (1984) using satellite tracking techniques and Crepon and others (1988) who examined the effect of wind on iceberg drift, along with more recent work using satellite-borne microwave backscatter experiments (Young, 1998) indicates that the motion of the larger icebergs is determined by the ocean currents. In turn, the ocean currents are influenced by the bathymetry. Figure 3 shows ocean bathymetry (after Row and Hastings, 1995; Row and others, 1995) in the iceberg observation area. Bindoff and others (2000) examined water circulation in the area. They noted the latitude, at each of eight north-south transects, at which the 'westward flow became eastward'. The dashed curve in Figure 3, through the latitudes listed by Bindoff and others, closely follows the near-shore bathymetry (at $\sim 1000 \mathrm{~m}$ depth). In Figure 2 we see that the same curve approximately envelops the southern boundary of the band of higher iceberg concentration between 90 and $150^{\circ} \mathrm{E}$. We will see in the next section that the iceberg concentration distribution at these longitudes has two maxima, corresponding with the two currents (the nearcoast, west-flowing east wind drift, and the east-flowing Circumpolar Current).

\section{SIZE DISTRIBUTION}

Figure $4 \mathrm{a}$ and $\mathrm{b}$ show iceberg concentration and iceberg volume, respectively, within $6 \mathrm{mi}$ (int., naut.) $(11.1 \mathrm{~km})$ radius (total and within different size categories up to $>200 \mathrm{~m}$ ), for the period 1984/85-1999/2000, as a function of latitude for each $10^{\circ}$ longitudinal section, $60-70^{\circ}$, 


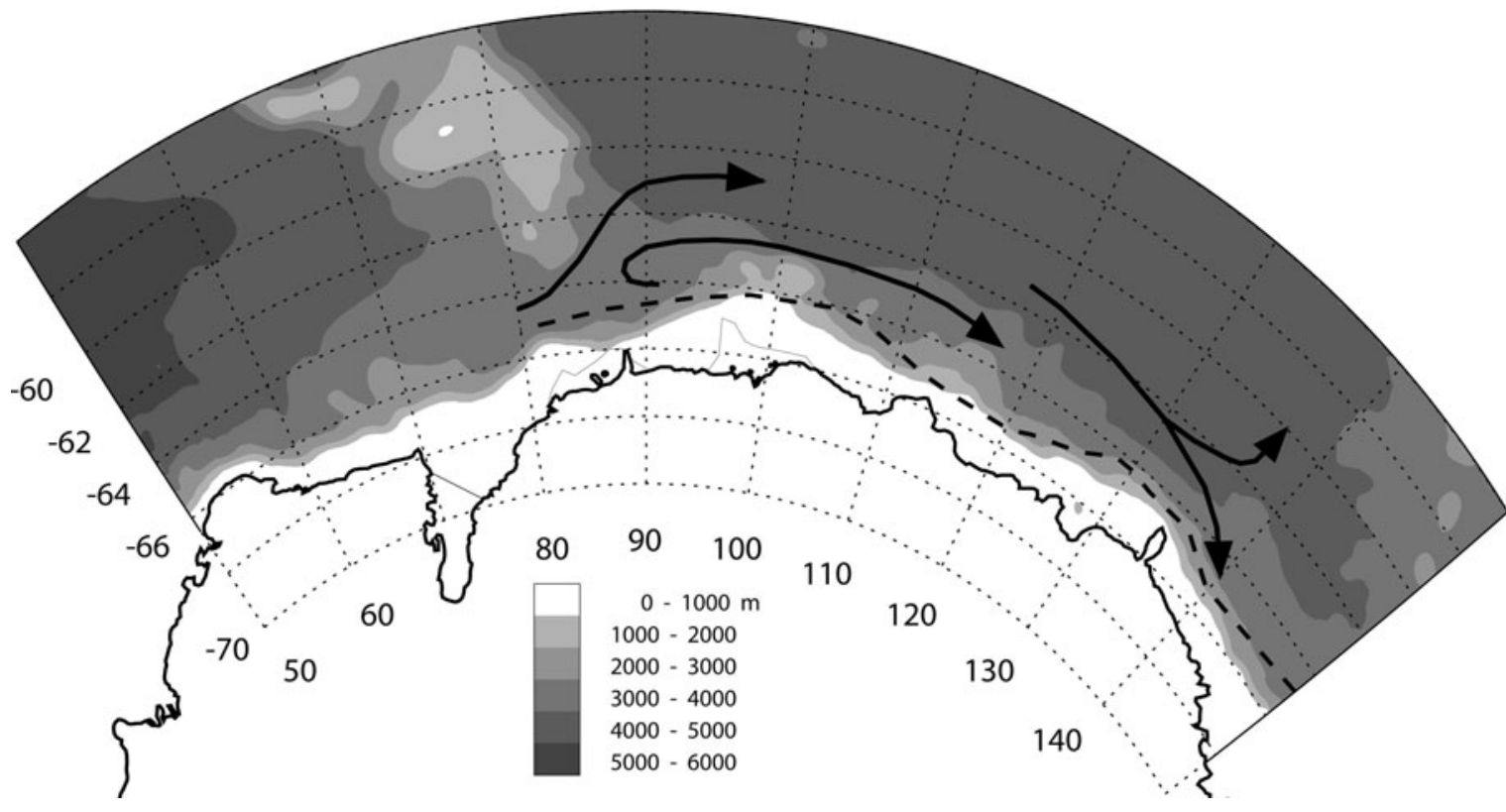

Fig. 3. Map showing contours of ocean depth (after Row and Hastings, 1995; Row and others, 1995), along with a schematic diagram of the ocean surface circulation (after Bindoff and others, 2000). The dashed curve, the slope current (Bindoff and others, 2000), is effectively the boundary between the west-flowing east wind drift and the east-flowing Circumpolar Current.

$70-80^{\circ}, \ldots, 140-150^{\circ} \mathrm{E}$ (see later for details of volume calculations). Figure $4 \mathrm{a}$ (plotted in reverse order on the longitude axis) can be compared with Hamley and Budd's (1986) figures 1 and 2, noting that Hamley and Budd's concentrations were observed over a $12 \mathrm{mi}$ (int., naut.) $(22.2 \mathrm{~km})$ radius. The general trend of the data is similar to that reported by Hamley and Budd. The 'total' plots of Figure $4 \mathrm{a}$ and $\mathrm{b}$ reflect the picture outlined above.

Near the coast (i.e. between the dashed curve of Figure 3 and the coast), icebergs tend to move towards the west in the east wind drift. At $\sim 80-90^{\circ} \mathrm{E}$, they drift northwards, influenced by the bathymetry in and northeast of Prydz Bay (northeast of the Amery Ice Shelf) as shown in Figure 3 (solid curves, after Bindoff and others (2000)), until they are caught, and carried towards the east, in the more northerly west-to-east flowing Circumpolar Current. While local eddies may also cause some south-to-north transfer of icebergs across the boundary between the two dominant currents, the north-to-south transfer is likely to be about the same. There is, therefore, an area of lower iceberg concentration between the two major currents. Thus, in Figure $4 \mathrm{a}$ and $\mathrm{b}$, at longitudes east of $90^{\circ} \mathrm{E}$ the curves exhibit two maxima in iceberg concentration and volume at the latitudes of the two currents, and, as noted in the previous section, the latitude of the enclosed minimum agrees well with the current direction change at locations listed by Bindoff and others (2000). The total number of icebergs reduces (due to dissolution - melting, breakage, etc.) east of $90^{\circ} \mathrm{E}$ until 120 $130^{\circ} \mathrm{E}$ where the concentration and total ice volume is relatively very low. Finally (from Fig. 4), following the Circumpolar Current, there are peaks in iceberg concentration and volume at $130-140$ and $140-150^{\circ} \mathrm{E}$ due to iceberg production by Ninnis and Mertz Glaciers.

Figure $5 \mathrm{a}$ is a plot of iceberg concentration (means across all latitudes) as a function of longitude. The pattern of increasing concentration from the west to $90-100^{\circ} \mathrm{E}$ in all size classes, and then the decrease in concentration as the icebergs are caught in the Circumpolar Current flowing east from $90-100^{\circ} \mathrm{E}$, is evident. Figure $5 \mathrm{~b}$, a similar plot but of iceberg volume, reveals that, primarily due to the presence of a few large $(>800 \mathrm{~m})$ icebergs in the west of the study area, the total volume decreases from west to east throughout the study region, but with a dip in the $80-90^{\circ} \mathrm{E}$ sector. In addition, comparison of Figure $5 \mathrm{a}$ and $\mathrm{b}$ shows that, although the numbers of smaller icebergs are greater, an extremely small percentage of the volume is included in the 25-100 m size category. The bulk of the ice is accounted for within the relatively few icebergs in size categories $>400 \mathrm{~m}$. Note for the plots of Figure 4 we found it most convenient to include size categories for the concentration data that included the smaller icebergs, then a '>200 m' category, yet in Figure $4 b$, only the larger icebergs were included with a ' $<400 \mathrm{~m}^{\prime}$ category.

At $80-90^{\circ} \mathrm{E}$, where the iceberg drift direction is primarily towards the north as they transfer from one current to the other, there is a relatively high concentration of icebergs across the full latitude band from the coast to the northern extent. West of $80^{\circ} \mathrm{E}$ and to the north, iceberg concentrations and volumes are relatively low, since, predominantly, they are drifting to the east. Near the coast the concentration is higher, due to production and grounding along the Mawson coast. Examination of the different size categories west of $80^{\circ} \mathrm{E}$ (Fig. 4a) reveals curves of similar shape and magnitude within each longitudinal section, i.e. at each longitude the contribution to the total concentration is approximately equal for each of the three size categories 25-100, 100-200 and (less clearly) >200 m. At 80-90 E, there is a decrease in iceberg concentration with increasing size category. From 60 to $62^{\circ} \mathrm{S}$ there is a greater contribution to the total concentration from the 25-100 m icebergs. Apart from this and a peak in concentration of $>200 \mathrm{~m}$ icebergs near the coast, the shape of the distribution is similar for each size category. East of $90^{\circ} \mathrm{E}$, while there is a decrease in iceberg concentration with increasing size category, most of the variability in the total concentration is due to variability in the 25-100 $\mathrm{m}$ category. As described above, this 

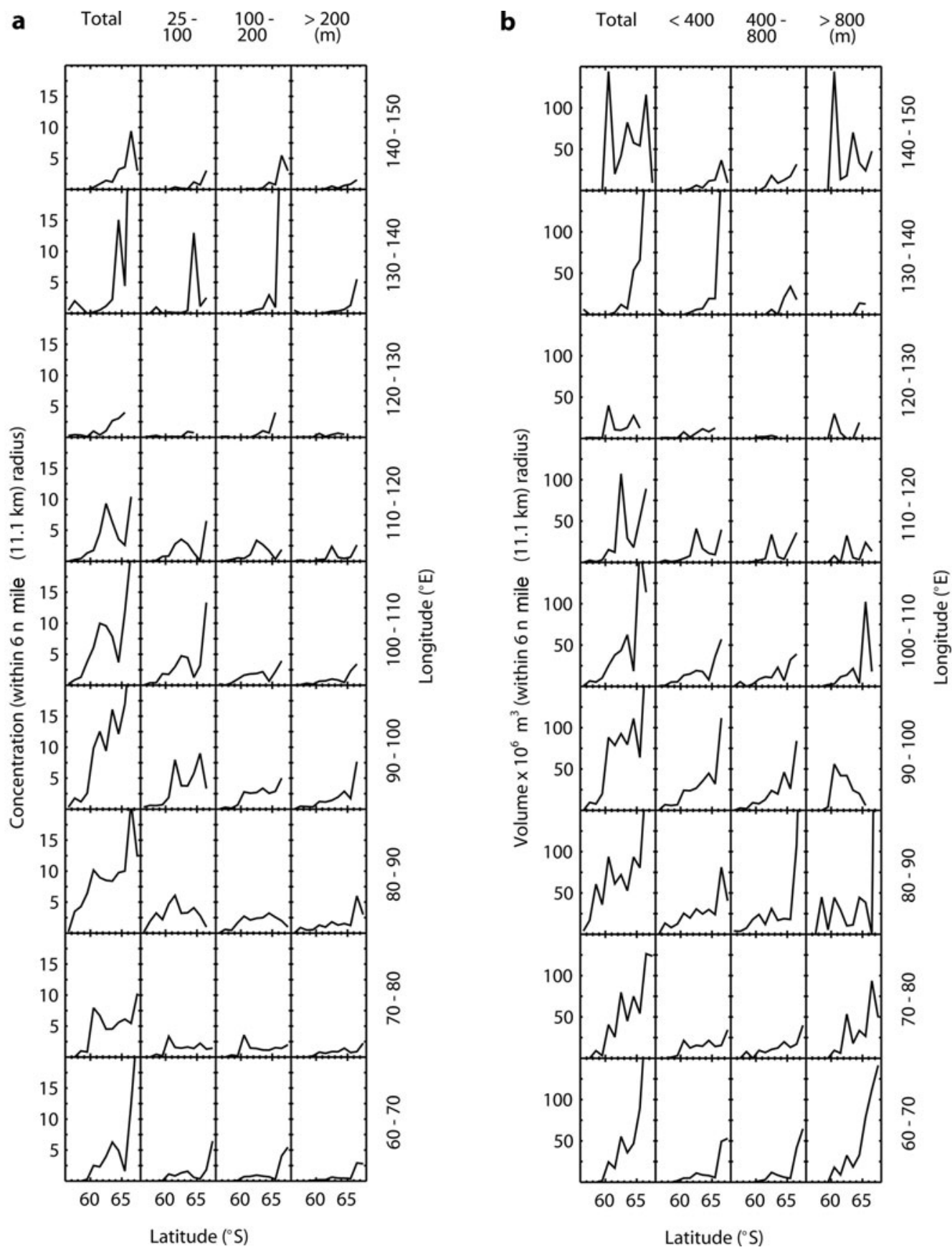

Fig. 4. Iceberg concentration (a) and total iceberg volume (b) within the observation radius of $6 \mathrm{mi}$ (int., naut.) (11.1 km) for the period $1984 / 85-1999 / 2000$, as a function of latitude for each $10^{\circ}$ longitudinal section, $60-70,70-80, \ldots, 140-150^{\circ}$ E. Data are accumulated in $1^{\circ}$ latitudinal increments, and are plotted for the total number of icebergs, and for each size category.

variability characterizes the two major currents in which these icebergs are transported.

In terms of iceberg total volume (Fig. 4b), there is a clear trend at every longitude for decreasing volume with decreasing latitude. Furthermore, while concentrations of the smaller size categories dominate, the trend in volume is controlled by the few large icebergs, especially in the western sectors of the study area where there are some large icebergs near the coast.

\section{TEMPORAL CHANGE}

With 16 years of data at our disposal we can examine whether there have been any significant changes with time, in the concentration, volume and distribution of icebergs. Figure $6 \mathrm{a}$ and $\mathrm{b}$ show the concentration and volume, respectively, of icebergs within $11.1 \mathrm{~km}$ (total across all size categories) in each of the $10^{\circ}$ longitudinal sectors, averaged over the two 5 year and one 6 year periods, 1984/85 austral summer to 1988/89, 1989/90-1993/94 and 1994/95-1999/ 2000. We have also included the iceberg concentrations and volumes for the period 1978/79-1983/84, i.e. the data examined by Hamley and Budd (1986). Both iceberg concentration and volume in the study area for 1984/85$1988 / 89$ are higher (on average by a factor $>2$ ) than in the following two periods. They are also higher than in the earlier 6 year period, but by a lesser amount. A study at the University of Sheffield, UK (personal communication from T. Silva, 2005) which examines the same iceberg dataset on 
a

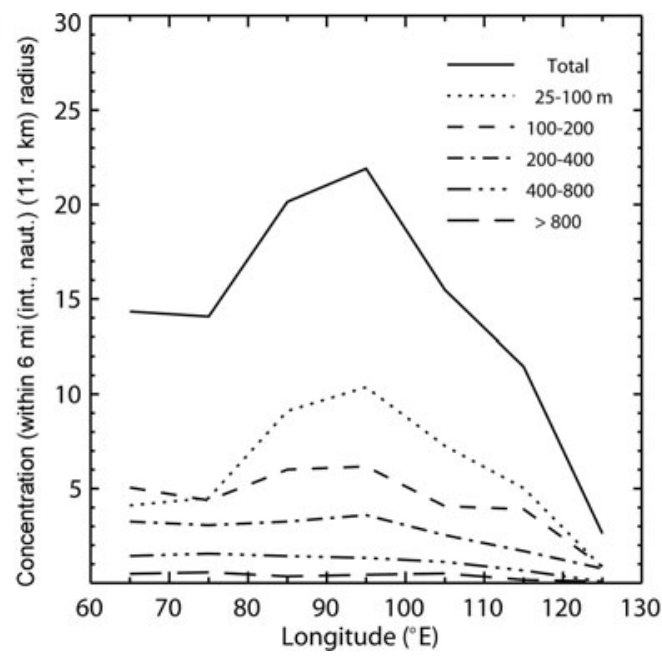

b

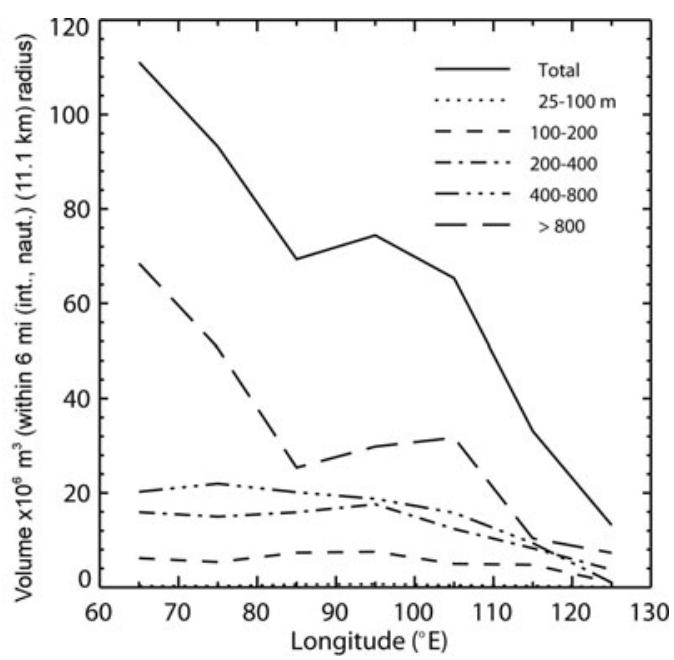

Fig. 5. Iceberg concentration (a) and volume (b) as a function of longitude, plotted for each size category and for the total number of icebergs.

an annual basis has also found a reduction in both the concentration and total volume of icebergs during the $1980 \mathrm{~s}$ with lower values during the 1990s. Volumes and concentrations were similar, however, in the $120-130^{\circ} \mathrm{E}$ sector and west of $80^{\circ} \mathrm{E}$. That is, the greater volume and concentration during the 1984/85-1988/89 period occurred between 80 and $120^{\circ} \mathrm{E}$, the same area as that fed by the gyre operating northeast of Prydz Bay. For the two later periods, they are similar in all longitudinal sectors.

Data from the SCAR Antarctic iceberg database at Norsk Polarinstitutt (personal communication from O. Orheim, 2003) covering observations around the entire Antarctic continent (more detailed in the Indian and Atlantic Ocean sectors than the Pacific sector) do not indicate significantly higher concentrations of icebergs in the 1984-88 period. This eliminates large continent-wide iceberg production as a cause of the higher concentrations in our study area. Maps of iceberg concentration and iceberg volume within $11.1 \mathrm{~km}$ radius for each of the four periods (Fig. 7a and b) show relatively low numbers in coastal areas during the two later periods. During the 1978/79-1983/84 and, especially, the 1984/85-1988/89 periods, however, higher coastal concentrations and volumes are evident, neighbouring the locations of ice shelves and outflow glaciers. Thus, the higher numbers seem to be the result of elevated local iceberg production. These observations demonstrate the episodic nature of iceberg release into the Southern Ocean, due to the episodic nature of the calving of large icebergs, especially from the large ice shelves (e.g. Fricker and others, 2002).

\section{DISSOLUTION RATES}

\section{The study area}

Hamley and Budd (1986) considered iceberg dissolution rates within the area bounded to the south by $64^{\circ} \mathrm{S}$ latitude and to the north by $59^{\circ} \mathrm{S}$ latitude. They made the assumption that all icebergs entering that latitudinal band between longitudes 90 and $100^{\circ} \mathrm{E}$ move to the east in the Circumpolar Current, remaining within these latitudinal limits. While they do not state it, it seems to us that they also assume for their calculation of dissolution rates that no new icebergs enter the study region east of $100^{\circ} \mathrm{E}$, or, at least, that the total mass of icebergs leaving the area is balanced by the occasional transfer into the area. A steady-state distribution (spatially and temporally) of icebergs is assumed for the study period. Thus (in the same way as astronomers view the life cycle of stars) a snapshot of the iceberg population at any one time can provide an idea of how a typical iceberg might progress from capture in the Circumpolar Current to finally end as freshwater input to the ocean.

The information from the previous sections allows us to better define an area to which the icebergs are confined. We define the northern limit of our study area as the northern extent of the long-term mean maximum sea ice, and the southern limit as the boundary between the east wind drift and the Circumpolar Current as tabulated by Bindoff and others (2000). Heil and Allison (1999) use the term Antarctic Divergence for this zone, in which they observe high shear in the sea-ice velocity distribution that divides the two surface currents. Our study area for estimation of dissolution rates is bounded by the two dashed curves of Figure 2 and is between 90 and $130^{\circ} \mathrm{E}$.

\section{Dissolution process}

Figure 8 shows the size frequency distribution of icebergs bounded by our northern and southern limit, in $10^{\circ}$ longitude steps (cf. Hamley and Budd, 1986, fig. 6). The similarity of the curves at each of the different longitudes indicates the dissolution process is similar at all longitudes. The shape of the curves, indicating an approximate doubling of frequency with a halving of iceberg size, indicates the dominant dissolution process is breakage (rather than melt) with melting of the smallest category only accounting for final dissolution. There are fewer data for icebergs in the $120-130^{\circ}$ E sector, leading to a less smooth curve.

\section{Iceberg area and volume calculations}

For calculations of iceberg area, $A$, i.e. the area of the top (or bottom) surface, we assume the observed linear dimension, $d$, is (on average) the diagonal of a rectangular iceberg with length to breadth ratio, $r$, so that

$$
A=R d^{2}
$$

where

$$
R=\frac{r}{r^{2}+1} \text {. }
$$

From a photographic survey of 525 icebergs, Dmitrash (1971) concluded $r$ was in the range 1.5-1.6. From satellite observations, Young and others (1998) found mean $r$ values 

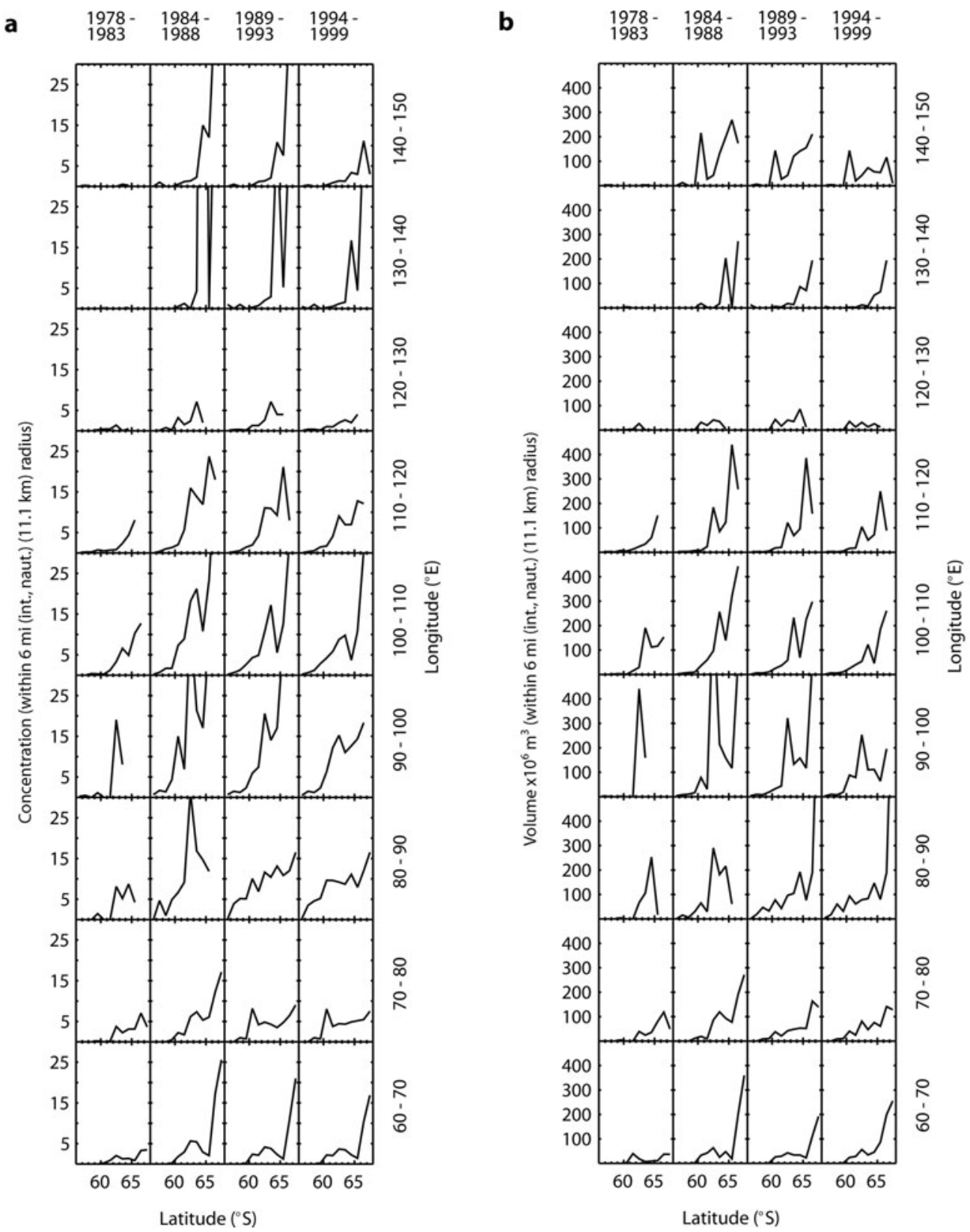

Fig. 6. Iceberg concentration (a) and volume (b) for each of the time periods, 1978/79-1983/84 (the data considered by Hamley and Budd, 1986), 1984/85-1988/89, 1989/90-1993/94 and 1994/95-1999/2000, as a function of latitude for each 10 longitudinal section, 60-70, $70-80, \ldots, 140-150^{\circ} \mathrm{E}$. The 'off-the-scale-value' in (a) for the $1984 / 85-1988 / 89$ period at $130-140^{\circ} \mathrm{E}$, is due to a single set of observations of in excess of 300 icebergs in the two smallest size categories.

for over 1000 icebergs near the coast within our study area to be in the range 1.3-1.5, over all size classes. The large icebergs calving from ice shelves are observed generally, however, to have $r$ values closer to 3. Using Hamley and Budd (1986) as a guide, we have assumed $r=1.5(R=0.46)$ for icebergs $<400 \mathrm{~m}$ in observed linear dimension, $r=2$ $(R=0.40)$ for icebergs $400-800 \mathrm{~m}$ and $r=3(R=0.30)$ for icebergs $>800 \mathrm{~m}$.

The iceberg volume, $V$, is

$$
V=\frac{h}{S} A,
$$

where $h$ is the iceberg height above the waterline (freeboard height) and $s$ is the ratio of height to total thickness.

For examination of factors controlling dissolution rate, it is also informative to investigate the total iceberg surface area below the ocean surface, $A_{\mathrm{w}}$, i.e. the area of iceberg in contact with the water,

$$
A_{\mathrm{w}}=\frac{(1-s)}{s} h 2 R d+A
$$

where

$$
R=\frac{(r+1)}{\sqrt{r^{2}+1}}
$$

i.e.

$$
\begin{aligned}
& r=1.5 \rightarrow R=1.39, \\
& r=2 \quad \rightarrow R=1.34, \\
& r=3 \quad \rightarrow R=1.26 .
\end{aligned}
$$

\section{Iceberg thickness}

Most of the large icebergs $(>400 \mathrm{~m})$ have calved from ice shelves, and the major Antarctic ice shelves have a 
a
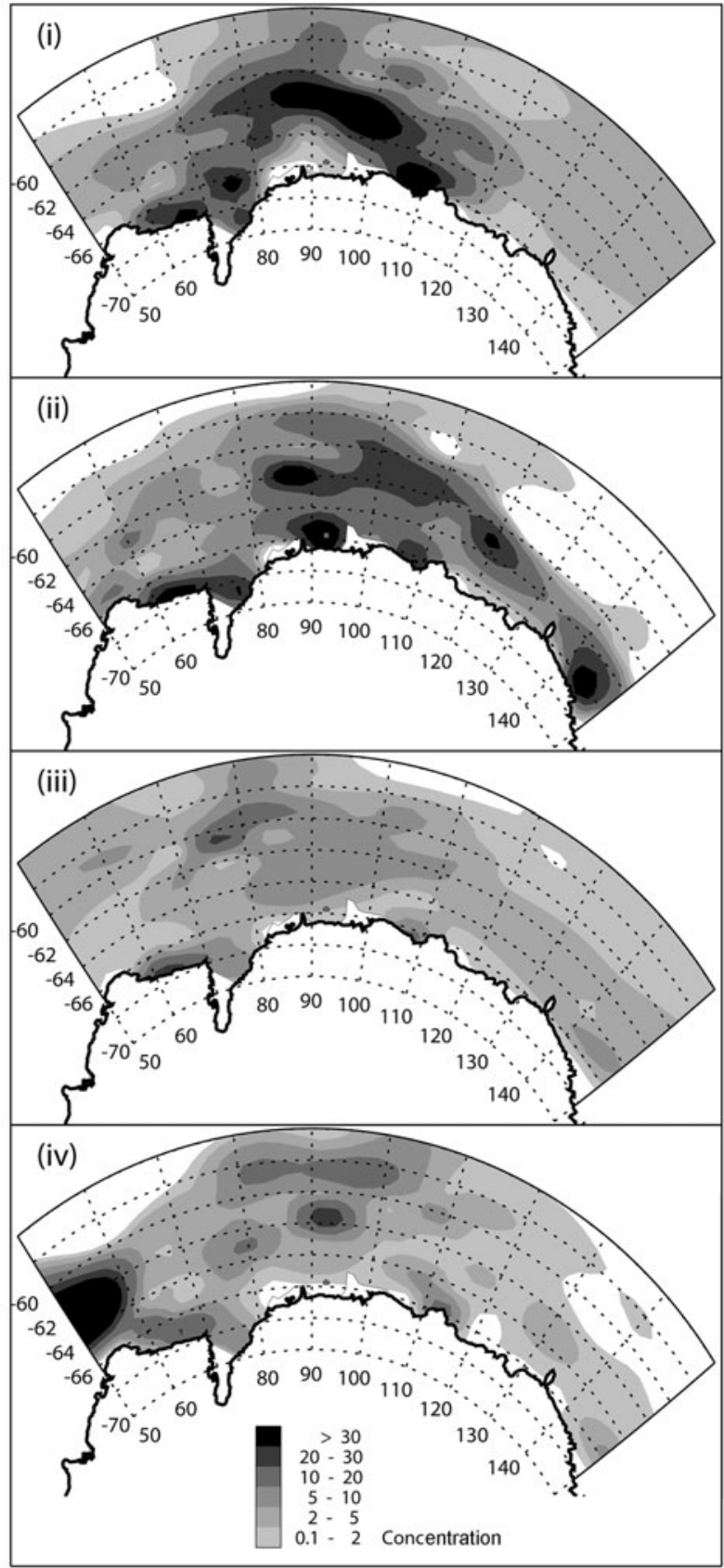

b
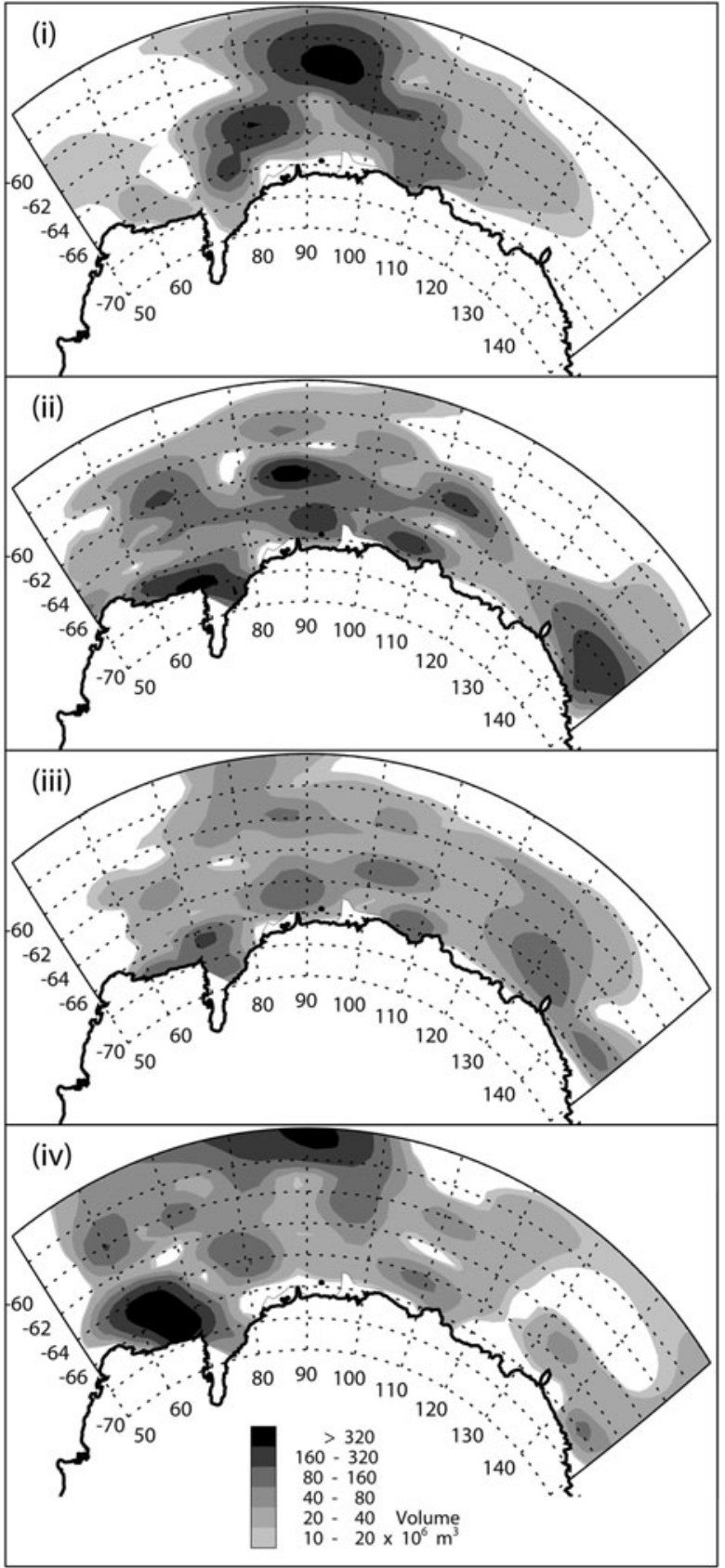

Fig. 7. Maps of iceberg concentration (a) and volume (b) for each of the four periods, (i) 1978/79-1983/84 (data adjusted, since the observation radius was $12 \mathrm{mi}$ (int., naut.) (22.2 km)), (ii) 1984/85-1988/89, (iii) 1989/90-1993/94 and (iv) 1994/95-1999/2000.

freeboard height of $\sim 30-40 \mathrm{~m}$ at the front. The Amery lce Shelf, the probable primary source of the largest icebergs within our study area, is $\sim 40 \mathrm{~m}$ high at the front. Analysis of 215 observations, from the current dataset, of iceberg height to length ratio gives a mean ratio of 0.092 , with standard deviation 0.046; i.e. for a $400 \mathrm{~m}$ iceberg, a height of $37 \mathrm{~m}$. A height to thickness ratio, $s$, of $1: 7$ is expected (Shabtaie and Bentley, 1982), and we assign these icebergs an average thickness of $250 \mathrm{~m}$. Note that Hamley and Budd (1986) indicate tabular icebergs $>60 \mathrm{~m}$ high (with a smooth curve in their figure 9 , at $\sim 60 \mathrm{~m}$ height). While we concede many of the observed data indicate heights in excess of $60 \mathrm{~m}$ for large tabular icebergs, we believe these are due to overenthusiastic observers.

The irregularly shaped (non-tabular) icebergs (which, for area and volume calculations, we continue to assume to be rectangular) and tabular icebergs that have calved from the fast-flowing coastal outflow glaciers (e.g. Ninnis, Mertz, Totten and Vanderford Glaciers) are often observed to be $\geq 50 \mathrm{~m}$ high and occasionally up to $60 \mathrm{~m}$ high. We assign a height of $50 \mathrm{~m}$ (and an average thickness of $300 \mathrm{~m}$; i.e. $s$ is $1: 6)$ to the size categories $100-200$ and $200-400 \mathrm{~m}$. Icebergs with linear dimension $<100 \mathrm{~m}$ are in the range $10-30 \mathrm{~m}$ high. They also repeatedly roll, so little snow cover is present and they are near-solid ice with negligible snow. An average thickness of $90 \mathrm{~m}$ is assigned to these smaller icebergs, i.e. $s=1: 9$.

\section{Concentration change}

Figure 9a (cf. Hamley and Budd, 1986, fig. 8) shows plots of iceberg concentration as a function of width for the longitudinal sections we wish to examine east of $90-100^{\circ} \mathrm{E}$. The 


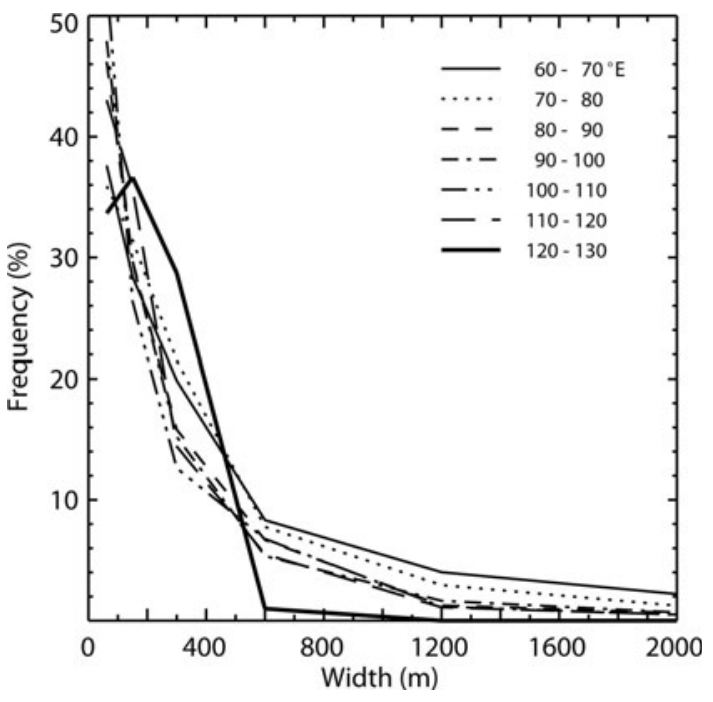

Fig. 8. The size frequency (concentration as per cent of total concentration within each size category) distribution, of icebergs bound by the northern and southern limits described in Figure 2, in $10^{\circ}$ longitudinal sectors as indicated.

figure indicates similar features to those of Figure 8 . The data of Figure 9a are also shown in Table 1, with calculations aimed at estimating dissolution rate. Table 1 is divided into four sections, (a) $90-100^{\circ} \mathrm{E}$, (b) $100-110^{\circ} \mathrm{E}$, (c) $110-120^{\circ} \mathrm{E}$ and (d) $120-130^{\circ} \mathrm{E}$, and three dissolution rates (averages across all size categories) are calculated between these sections.

\section{Volume change}

Figure $9 \mathrm{~b}$ is a plot of total iceberg volume (based on the above assumptions) within $6 \mathrm{mi}$ (int., naut.) $(11.1 \mathrm{~km})$ radius, as a function of width for the longitudinal sections in our study area east of $90-100^{\circ} \mathrm{E}$. Again, the dominance of the larger icebergs (especially those in the 400-800 m category), in terms of total volume, is demonstrated. The figure also highlights how the large volume of icebergs over all size categories, except the smallest, decreases to almost zero by the time they have drifted from $90-100$ to $120-130^{\circ} \mathrm{E}$. At $120-130^{\circ} \mathrm{E}$, only a few icebergs, mostly in the $200-400 \mathrm{~m}$ size category, remain.

Table 1 shows calculations, based on the observations and the above assumptions, of the average volume of ice per $11.1 \mathrm{~km}$ radius within each $10^{\circ}$ sector of our study area, for each size category. The total volumes (per $11.1 \mathrm{~km}$ radius) are, for $90-100^{\circ} \mathrm{E}, 6.96 \times 10^{7} \mathrm{~m}^{3}$; for $100-110^{\circ} \mathrm{E}$, $4.23 \times 10^{7} \mathrm{~m}^{3}$ (a decrease as the icebergs drift from the previous $10^{\circ}$ sector to this, of $2.73 \times 10^{7} \mathrm{~m}^{3}$ or $39.2 \%$ ); for $110-120^{\circ} \mathrm{E}, 1.95 \times 10^{7} \mathrm{~m}^{3}$ (a decrease of $2.28 \times 10^{7} \mathrm{~m}^{3}$ or $53.9 \%$ ); and for $120-130^{\circ} \mathrm{E}, 9.48 \times 10^{6} \mathrm{~m}^{3}$ (a decrease of $1.00 \times 10^{7} \mathrm{~m}^{3}$ or $51.4 \%$ ). These calculations compare favourably with those of Hamley and Budd (1986) who found (see their table II) a decrease in total ice volume of $48.4 \%, 57.0 \%$ and $45.3 \%$ across the three $10^{\circ}$ sector boundaries. The total iceberg volume remaining in the study area in the $120-130^{\circ}$ E sector is $9.48 \times 10^{6} \mathrm{~m}^{3}$, just $13.6 \%$ of the volume in the $90-100^{\circ} \mathrm{E}$ sector.

\section{Current speeds, residence times and dissolution rates}

To calculate dissolution rates, we require drift rates and, from these, mean residence times of icebergs in each of the $10^{\circ}$ longitudinal sectors of the study area. The earliest measurements in this regard are from the First GARP Global Experiment (FGGE) (Hofmann, 1985) which included only a very few drifting buoys south of $60^{\circ} \mathrm{S}$. The iceberg-tracking project of Tchernia and Jeannin (1984), which included several icebergs tracked by the AAP within the study area, provides some additional data. Budd (1986) summarized the data available at that time, giving a mean west to east drift component at $55-60^{\circ} \mathrm{S}$, between 90 and $120^{\circ} \mathrm{E}$, of $0.11 \mathrm{~m} \mathrm{~s}^{-1}\left(9.50 \mathrm{~km} \mathrm{~d}^{-1}\right)$ and between 120 and $150^{\circ} \mathrm{E}$ of $0.21 \mathrm{~m} \mathrm{~s}^{-1}\left(18.14 \mathrm{~km} \mathrm{~d}^{-1}\right)$.

From buoys placed within the sea-ice zone such that they freeze into the sea ice, Heil and Allison (1999) examined mean daily sea-ice drift velocities. Most of their study is in the east wind drift, but a few measurements are north of the Antarctic Divergence, where they provide a mean sea-ice drift velocity between 80 and $97.5^{\circ} \mathrm{E}$ of $0.13 \mathrm{~m} \mathrm{~s}^{-1}\left(11.23 \mathrm{~km} \mathrm{~d}^{-1}\right)$ and between 97.5 and $100^{\circ} \mathrm{E}$ of $0.23 \mathrm{~m} \mathrm{~s}^{-1}\left(19.87 \mathrm{~km} \mathrm{~d}^{-1}\right)$. These speeds are similar to Budd's (1986) mean west to east drift components quoted

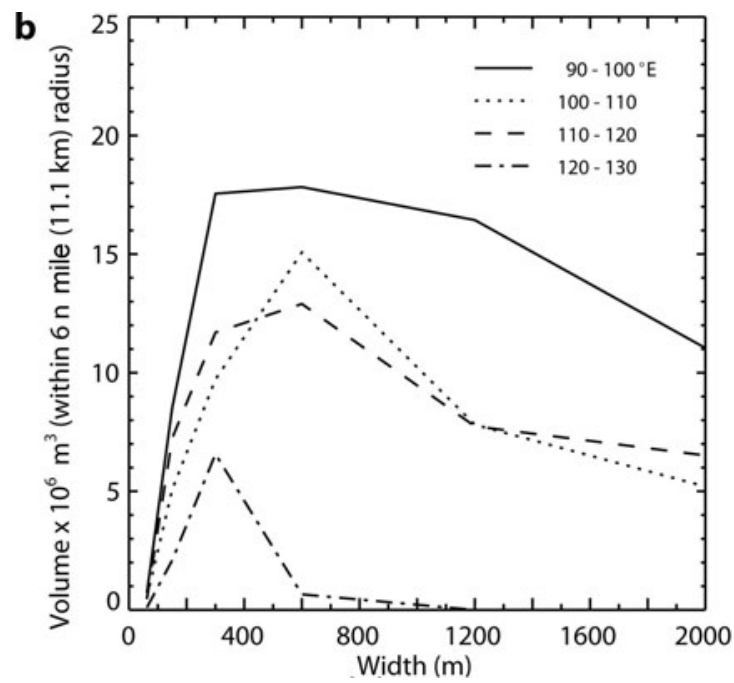

Fig. 9. Iceberg concentration (a) and volume (b) plotted as a function of width, within each $10^{\circ}$ longitudinal section of our dissolution study area. 
Table 1. Details of area and volume calculations, in $10^{\circ}$ longitudinal sectors and different size categories, for icebergs moving towards the east in the Antarctic Circumpolar Current. Concentration, surface area, water contact area and volume are average quantities within the observation circle, of radius $6 \mathrm{mi}$ (int., naut.) $(11.1 \mathrm{~km})$

\begin{tabular}{|c|c|c|c|c|c|}
\hline $\begin{array}{l}\text { Size range } \\
\mathrm{m}\end{array}$ & Concentration & $\begin{array}{c}\text { Surface area, } A \\
\mathrm{~m}^{2}\end{array}$ & $\begin{array}{c}\text { Water contact area, } A_{\mathrm{w}} \\
\mathrm{m}^{2}\end{array}$ & $\begin{array}{c}\text { Volume, } V \\
\mathrm{~m}^{3}\end{array}$ & $\%$ of total volume \\
\hline
\end{tabular}

(a) $90-100^{\circ} \mathrm{E}$

25-100

100-200

200-400

400-800

$800-1600$

1600-3200

Total

(b) $100-110^{\circ} \mathrm{E}$

25-100

100-200

200-400

400-800

800-1600

1600-3200

Total

Ice loss per $10^{\circ}$

$\%$ loss

(c) $110-120^{\circ} \mathrm{E}$

25-100

100-200

200-400

400-800

800-1600

1600-3200

Total

Ice loss per $10^{\circ}$

$\%$ loss

(d) $120-130^{\circ} \mathrm{E}$

25-100 0.62

100-200 0.67

200-400 0.53

400-800 0.02

800-1600 0.00

1600-3200 0.00

Total

Ice loss per $10^{\circ}$

$\%$ loss

2.80

2.32

0.94
0.36

0.07

0.01

0.00

$\begin{array}{ll}7.96 \times 10^{3} & 6.71 \times 10^{4} \\ 2.84 \times 10^{4} & 3.21 \times 10^{5} \\ 5.84 \times 10^{4} & 3.60 \times 10^{5} \\ 7.20 \times 10^{4} & 2.44 \times 10^{5} \\ 6.48 \times 10^{4} & 1.68 \times 10^{5} \\ 3.46 \times 10^{4} & 6.05 \times 10^{4} \\ 2.66 \times 10^{5} & \end{array}$

$4.95 \times 10^{4}$

$5.88 \times 10^{3}$
$1.69 \times 10^{4}$

$3.23 \times 10^{4}$

$6.05 \times 10^{4}$

$3.02 \times 10^{4}$

$1.73 \times 10^{4}$

$1.63 \times 10^{5}$

$1.91 \times 10^{5}$

$1.99 \times 10^{5}$

$2.05 \times 10^{5}$

$7.85 \times 10^{4}$

$3.03 \times 10^{4}$

$\begin{array}{ll}8.05 \times 10^{2} & 3.82 \times 10^{4} \\ 1.07 \times 10^{4} & 2.59 \times 10^{5} \\ 1.73 \times 10^{4} & 2.18 \times 10^{5} \\ 2.30 \times 10^{4} & 1.47 \times 10^{5} \\ 1.34 \times 10^{4} & 6.17 \times 10^{4} \\ 7.68 \times 10^{3} & 2.07 \times 10^{4}\end{array}$

$7.29 \times 10^{4}$

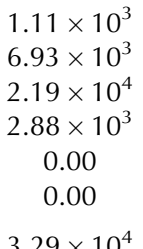

$3.29 \times 10^{4}$

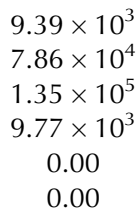

$7.16 \times 10^{5}$

$8.51 \times 10^{6}$

$1.75 \times 10^{7}$

$1.80 \times 10^{7}$

$1.62 \times 10^{7}$

$8.64 \times 10^{6}$

$6.96 \times 10^{7}$

$5.29 \times 10^{5}$

$5.06 \times 10^{6}$

$9.69 \times 10^{6}$

$1.51 \times 10^{7}$

$7.56 \times 10^{6}$

$4.32 \times 10^{6}$

$4.23 \times 10^{7}$

$2.73 \times 10^{7}$

39.2

$\begin{array}{rr}7.25 \times 10^{4} & 0.5 \\ 3.20 \times 10^{6} & 16.4 \\ 5.19 \times 10^{6} & 26.6 \\ 5.76 \times 10^{6} & 29.5 \\ 3.36 \times 10^{6} & 17.2 \\ 1.92 \times 10^{6} & 9.8 \\ 1.95 \times 10^{7} & 100\end{array}$

$2.28 \times 10^{7}$

53.9

$1.00 \times 10^{5}$

$2.08 \times 10^{6}$

$6.58 \times 10^{6}$

$7.20 \times 10^{5}$

0.00

0.00

1.0

12.2

25.2

25.9

23.3

12.4

100

$9.48 \times 10^{6}$

$1.00 \times 10^{7}$

51.4

\section{2 \\ 12.0 \\ 22.9 \\ 35.8 \\ 17.9 \\ 10.2 \\ 100}

100

1.1

21.9

69.4

7.6

0.0

0.0

100 above. Bindoff and others (2000) provide updated modelled current speeds, again predominantly south of the Antarctic Divergence, but with a few measurements further north. New data (Table 2) from N. Bindoff and C. Domingues (personal communication, 2003) indicate current speeds less than one-third of the above values for the east-flowing water north of the Antarctic Divergence. The mean speed across the longitudinal span from 95 to $135^{\circ} \mathrm{E}$ in the $60-62^{\circ} \mathrm{S}$ band is $3.0 \mathrm{~km} \mathrm{~d}^{-1}$. Note the low speeds in the intermediate band, and the higher east to west speeds south of the Divergence. Bindoff and Domingues' calculations are, however, based on geostrophic considerations, i.e. neglecting wind effects, and may underestimate current speeds by as much as $50 \%$.

Hamley and Budd (1986) assumed an average iceberg speed through their study area of $5.0 \mathrm{~km} \mathrm{~d}^{-1}$, equating to a residence time of 107 days per $10^{\circ}$ longitudinal sector $\left(532.6 \mathrm{~km}\right.$ at $\left.61.5^{\circ} \mathrm{S}\right)$, i.e. a total residence time across three sectors, $T_{\mathrm{R}}=321$ days. They noted that one iceberg had moved through the study area at $7.94 \mathrm{~km} \mathrm{~d}^{-1}$ but considered this to be the maximum likely speed because icebergs were frequently caught in large-scale eddies, so that the residence time in the area is increased. We assume (1) the same residence time as Hamley and Budd for each of the $10^{\circ}$ sectors and (2) a residence time of 177 days per $10^{\circ}$ longitude, corresponding to an iceberg drift speed of $3.0 \mathrm{~km} \mathrm{~d}^{-1}$, i.e. $T_{\mathrm{R}}=531$ days, to estimate half-lives, $T_{1 / 2}$, for each size range:

$$
\begin{aligned}
T_{1 / 2} & =\frac{V_{\mathrm{i}}}{2} \frac{T_{\mathrm{R}}}{V_{\mathrm{R}}} \\
V_{\mathrm{R}} & =V_{\mathrm{i}}-V_{\mathrm{f}}
\end{aligned}
$$


Table 2. Modelled oceanographic data for the study area (personal communication from N. Bindoff and C. Domingues, 2003), providing a 10 year mean picture. Depth integration of the data is a linear interpolation using data at 10,32, 62, 104, 161 and $238 \mathrm{~m}$ depth. Longitude and latitude provide the position of the midpoints of data bins of $2^{\circ}$ latitude $\times 10^{\circ}$ longitude (i.e. data in the first row pertain to the area $\left.60-62{ }^{\circ} \mathrm{S}, 95.0-105.0^{\circ} \mathrm{E}\right)$

\begin{tabular}{|c|c|c|c|c|c|c|}
\hline $\begin{array}{l}\text { Latitude } \\
{ }^{\circ} \mathrm{S}\end{array}$ & $\begin{array}{c}\text { Longitude } \\
{ }^{\circ} \mathrm{E}\end{array}$ & $\begin{array}{l}\text { Zonal velocity } \\
\qquad \mathrm{km} \mathrm{d}^{-1}\end{array}$ & $\begin{array}{l}\text { Meridional velocity } \\
\qquad \mathrm{km} \mathrm{d}^{-1}\end{array}$ & $\begin{array}{l}\text { Velocity magnitude } \\
\qquad \mathrm{km} \mathrm{d}^{-1}\end{array}$ & Velocity bearing & $\begin{array}{c}\text { Temperature } \\
{ }^{\circ} \mathrm{C}\end{array}$ \\
\hline 61.0 & 100.0 & 1.85 & 0.02 & 1.85 & 90.54 & 1.35 \\
\hline 63.0 & 100.0 & -1.29 & -0.15 & 1.29 & 275.75 & 0.64 \\
\hline 65.0 & 100.0 & -5.52 & -1.37 & 5.65 & 282.10 & -1.38 \\
\hline 61.0 & 110.0 & 3.68 & -0.48 & 3.70 & 83.57 & 1.24 \\
\hline 63.0 & 110.0 & 0.65 & -0.23 & 0.68 & 72.95 & 0.84 \\
\hline 65.0 & 110.0 & -6.26 & 0.17 & 6.26 & 268.65 & -0.85 \\
\hline 61.0 & 120.0 & 4.04 & 0.06 & 4.04 & 90.73 & 1.08 \\
\hline 63.0 & 120.0 & 1.39 & -0.59 & 1.48 & 69.87 & 0.93 \\
\hline 65.0 & 120.0 & -4.16 & -0.93 & 4.24 & 124.31 & -0.44 \\
\hline 61.0 & 130.0 & 2.50 & -0.40 & 2.52 & 82.12 & 0.93 \\
\hline 63.0 & 130.0 & 1.87 & -0.66 & 1.96 & 73.08 & 0.86 \\
\hline 65.0 & 130.0 & -4.24 & -1.60 & 4.46 & 124.18 & -1.12 \\
\hline
\end{tabular}

where $V_{i}$ is initial (i.e. within the $90-100^{\circ} \mathrm{E}$ sector) total iceberg volume within the size range, and $V_{\mathrm{f}}$ is the final (i.e. within the $120-130^{\circ} \mathrm{E}$ sector) total iceberg volume within the same size range. Table 3 shows calculated halflives for each size category. The mean half-life across all sizes is 191 days with standard deviation 38 days assuming an iceberg drift speed of $5 \mathrm{kmd}^{-1}$, and 318 days with standard deviation 63 days for an iceberg drift speed of $3 \mathrm{~km} \mathrm{~d}^{-1}$. The half-life calculated for the total of all icebergs is 186 days (for drift speed $5 \mathrm{~km} \mathrm{~d}^{-1}$ ) or 310 days (drift speed $3 \mathrm{~km} \mathrm{~d}^{-1}$ ). Hamley and Budd (1986) estimated a half-life of 0.2 years ( $\sim 73$ days), pointing out that this was about the same across all size categories.

Assuming the dissolution of the smallest iceberg category is due entirely to melt, we can use the half-life to estimate a linear melt rate. The shape of the iceberg must also be assumed, and a cube with longest linear dimension (the diagonal) $62.5 \mathrm{~m}$ (i.e. the mean dimension of the smallest category) has sides of $44.2 \mathrm{~m}$, and volume $86351 \mathrm{~m}^{3}$. In one

Table 3. Half-life calculations for each size category, and for the total iceberg volume. The calculations shown are across the full study area, ${ }^{*} 90-130^{\circ} \mathrm{E}$. It is assumed that the total residence time is (a) $3 \times 107$ days and (b) $3 \times 177$ days

\begin{tabular}{lcc}
\hline Size range & Half-life $(\mathrm{a})$ & Half-life $(\mathrm{b})$ \\
$\mathrm{m}$ & days & days \\
\hline $25-100$ & 187 & 311 \\
$100-200$ & 212 & 353 \\
$200-400$ & 257 & 428 \\
$400-800$ & 167 & 278 \\
$800-1600$ & $161(135)$ & $268(223)$ \\
$1600-3200$ & $161(138)$ & $268(228)$ \\
Mean & 191 & 318 \\
Standard deviation & 38 & 310 \\
Total iceberg volume & 186 &
\end{tabular}

${ }^{*}$ For the two largest size categories, the iceberg counts in the $120-130^{\circ} \mathrm{E}$ sector were zero. The numbers in parentheses indicate the half-life based on calculations for two longitudinal sectors only. half-life the volume is reduced to $43175 \mathrm{~m}^{3}$, i.e. a cube with sides of $35.1 \mathrm{~m}$. The linear melt rate for the smallest category is then $(44.2-35.1) / 187=0.049 \mathrm{~m} \mathrm{~d}^{-1}$ (assuming from Table 3 a half-life of 187 days at drift speed $5 \mathrm{~km} \mathrm{~d}^{-1}$ ) or $(44.2-35.1) / 311=0.029 \mathrm{~m} \mathrm{~d}^{-1}$ (assuming a half-life of 311 days at drift speed $3 \mathrm{~km} \mathrm{~d}^{-1}$ ). Some previous studies (e.g. Budd and others, 1980; Neshyba and Josberger, 1980; Russell-Head, 1980) have estimated melt rates in the temperature range $0-2{ }^{\circ} \mathrm{C}$ to be $\sim 0.1 \mathrm{~m} \mathrm{~d}^{-1}$. Hamley and Budd (1986) estimated a melt rate of $0.12 \mathrm{~m} \mathrm{~d}^{-1}$, but it is unclear how their estimate was made. While we suggest here that iceberg melt rates may be half to a quarter of those estimated in previous work, it needs to be recognized that information concerning drift speeds is most wanting.

An alternative approach to the problem of estimating dissolution rates is to assume the volume loss as icebergs move from one $10^{\circ}$ sector to the next is related to the iceberg area exposed to ocean water, $A_{\mathrm{w}}$, i.e. to the total iceberg surface area below the water surface. This quantity is tabulated for each iceberg size category in each $10^{\circ}$ longitude sector in Table 1. Table 4 and Figure 10 show volume loss (calculated by subtracting the total ice volume per $11.1 \mathrm{~km}$ observation area in each $10^{\circ}$ sector from the volume in the $10^{\circ}$ sector immediately to the west) as a function of $A_{\mathrm{w}}$. Values used in Table 4 and Figure 10 are means across each interval pair. There are thus three points for each size category.

From Figure 10 we see that the data fall into three distinct groups: the largest icebergs (all those $>800 \mathrm{~m}$, and two of the three points for the $400-800 \mathrm{~m}$ category), the mid-sized icebergs (all the icebergs in the size range 100-400 $\mathrm{m}$ and the one datum from the $400-800 \mathrm{~m}$ range in the longitudinal sector $90-100^{\circ} \mathrm{E}$ to $100-110^{\circ} \mathrm{E}$ ) and the smallest icebergs (all those $<100 \mathrm{~m}$ ). For the largest icebergs, Figure 10 indicates a straight line relationship $\left(r^{2}=0.94\right)$ between surface area below water and volume loss, with slope $47.5 \mathrm{~m}$. This quantity, $47.5 \mathrm{~m}$ per $10^{\circ}$ of longitude, can be regarded as a linear dissolution rate. Note, however, that this applies to five surfaces (four sides and the base) of the iceberg, and it therefore might be expected to be a factor of up to five greater than the linear dissolution rate estimated above (i.e. $\sim 9.5 \mathrm{~m}$ per $10^{\circ}$ of longitude, or $0.089 \mathrm{~m} \mathrm{~d}^{-1}$ for a 
Table 4. Iceberg surface area in contact with ocean water (mean across each pair of $10^{\circ}$ sectors), along with iceberg volume loss and mass of freshwater input to the ocean, for each size category, as icebergs move (three steps) from one $10^{\circ}$ longitudinal to the next

\begin{tabular}{|c|c|c|c|c|c|c|}
\hline Longitudinal sector & $\begin{array}{l}\text { Iceberg size } \\
\text { category }\end{array}$ & $\begin{array}{c}\text { Mean contact } \\
\text { area }\end{array}$ & $\begin{array}{c}\text { Volume loss } \\
\text { per } 11.1 \mathrm{~km} \text { radius }\end{array}$ & $\begin{array}{l}\text { Freshwater input } \\
\text { per } 11.1 \mathrm{~km} \text { radius }\end{array}$ & $\begin{array}{l}\text { Freshwater input } \\
\text { per unit area }\end{array}$ & $\begin{array}{c}\text { Freshwater input } \\
\text { per unit area per year }\end{array}$ \\
\hline${ }^{\circ} \mathrm{E}$ & $\mathrm{m}$ & $\mathrm{m}^{2}$ & $\mathrm{~m}^{3}$ & $\mathrm{~kg}$ & $\mathrm{~kg} \mathrm{~m}^{-2}$ & $\mathrm{~kg} \mathrm{~m}^{-2} \mathrm{a}^{-1}$ \\
\hline $90-100$ to $100-110$ & $\begin{array}{c}0-100 \\
100-200 \\
200-400 \\
400-800 \\
800-1600 \\
1600-3200\end{array}$ & $\begin{array}{l}5.83 \times 10^{4} \\
2.56 \times 10^{5} \\
2.80 \times 10^{5} \\
2.25 \times 10^{5} \\
1.23 \times 10^{5} \\
4.54 \times 10^{4}\end{array}$ & $\begin{array}{l}1.88 \times 10^{5} \\
3.45 \times 10^{6} \\
7.82 \times 10^{6} \\
2.88 \times 10^{6} \\
8.64 \times 10^{6} \\
4.32 \times 10^{6}\end{array}$ & $\begin{array}{l}1.72 \times 10^{8} \\
2.96 \times 10^{9} \\
6.71 \times 10^{9} \\
2.54 \times 10^{9} \\
7.63 \times 10^{9} \\
3.81 \times 10^{9}\end{array}$ & $\begin{array}{r}0.44 \\
7.65 \\
17.34 \\
6.56 \\
19.71 \\
9.84\end{array}$ & $\begin{array}{r}1.5 \\
26.1 \\
59.2 \\
22.4 \\
67.2 \\
33.6\end{array}$ \\
\hline Total & & & $2.73 \times 10^{7}$ & $2.38 \times 10^{10}$ & 61.54 & 210 \\
\hline $100-110$ to $110-120$ & $\begin{array}{c}0-100 \\
100-200 \\
200-400 \\
400-800 \\
800-1600 \\
1600-3200\end{array}$ & $\begin{array}{l}4.39 \times 10^{4} \\
2.25 \times 10^{5} \\
2.09 \times 10^{5} \\
1.76 \times 10^{5} \\
7.01 \times 10^{4} \\
2.55 \times 10^{4}\end{array}$ & $\begin{array}{l}4.56 \times 10^{5} \\
1.86 \times 10^{6} \\
4.50 \times 10^{6} \\
9.36 \times 10^{6} \\
4.20 \times 10^{6} \\
2.40 \times 10^{6}\end{array}$ & $\begin{array}{l}4.17 \times 10^{8} \\
1.60 \times 10^{9} \\
3.86 \times 10^{9} \\
8.26 \times 10^{9} \\
3.71 \times 10^{9} \\
2.12 \times 10^{9}\end{array}$ & $\begin{array}{r}1.08 \\
4.12 \\
9.97 \\
21.35 \\
9.58 \\
5.47\end{array}$ & $\begin{array}{r}3.6 \\
14.1 \\
34.0 \\
72.8 \\
32.7 \\
18.7\end{array}$ \\
\hline Total & & & $2.28 \times 10^{7}$ & $2.00 \times 10^{10}$ & 51.58 & 176 \\
\hline $110-120$ to $120-130$ & $\begin{array}{c}0-100 \\
100-200 \\
200-400 \\
400-800 \\
800-1600 \\
1600-3200\end{array}$ & $\begin{array}{l}2.38 \times 10^{4} \\
1.69 \times 10^{5} \\
1.77 \times 10^{5} \\
7.84 \times 10^{4} \\
3.09 \times 10^{4} \\
1.04 \times 10^{4}\end{array}$ & $\begin{array}{r}-2.78 \times 10^{4} \\
1.12 \times 10^{6} \\
-1.39 \times 10^{6} \\
5.04 \times 10^{6} \\
3.36 \times 10^{6} \\
1.92 \times 10^{6}\end{array}$ & $\begin{aligned}-2.54 & \times 10^{7} \\
9.61 & \times 10^{8} \\
-1.19 & \times 10^{9} \\
4.45 & \times 10^{9} \\
2.97 & \times 10^{9} \\
1.70 & \times 10^{9}\end{aligned}$ & $\begin{array}{r}-0.07 \\
2.48 \\
-3.07 \\
11.50 \\
7.67 \\
4.39\end{array}$ & $\begin{array}{r}-0.2 \\
8.5 \\
-10.5 \\
39.2 \\
26.2 \\
14.9\end{array}$ \\
\hline Total & & & $1.01 \times 10^{7}$ & $8.91 \times 10^{9}$ & 22.90 & 78 \\
\hline
\end{tabular}

residence time of 107 days or $0.054 \mathrm{~m} \mathrm{~d}^{-1}$ for a residence time of 177 days).

There is also a linear relation (although not as strong as for the larger icebergs; $\left.r^{2}=0.68\right)$ between the surface area below water and volume loss for the mid-sized icebergs. Note also in this set of data, one point indicating a volume gain. This, of course, can happen because the study is statistical in nature, and a large number of breakages of larger icebergs in the sector to the west can result in an increase in icebergs of one particular size to the east, although the total iceberg volume is decreased. The data indicate that these mid-sized icebergs have in total (noting there are many more icebergs in this size category) a greater surface area under water than the larger icebergs (thus the shift on the area scale by about $20 \times 10^{4} \mathrm{~m}^{2}$ ). The dissolution rate (the slope of the straight line) for these data is $59.8 \mathrm{~m}$ per $10^{\circ}$ longitude and, again, this is expected to be primarily due to breakage into smaller size categories.

The three points for the smallest size category indicate low surface area and low volume loss. No strong relationship is evident between volume loss and area exposed to water, and dissolution of these icebergs is almost entirely due to melt.

\section{TEMPERATURE}

Water temperatures, integrated over depths of $10,32,62$, 104, 161 and $238 \mathrm{~m}$, are included in Table 2 (personal communication from N. Bindoff and C. Domingues, 2003). The mean temperature across the study area between 60 and $62^{\circ} \mathrm{S}$ is $1.15^{\circ} \mathrm{C}$, and between 62 and $64^{\circ} \mathrm{S}$ is $0.82^{\circ} \mathrm{C}$. Thus an estimate of $1^{\circ} \mathrm{C}$ for the mean temperature within the study

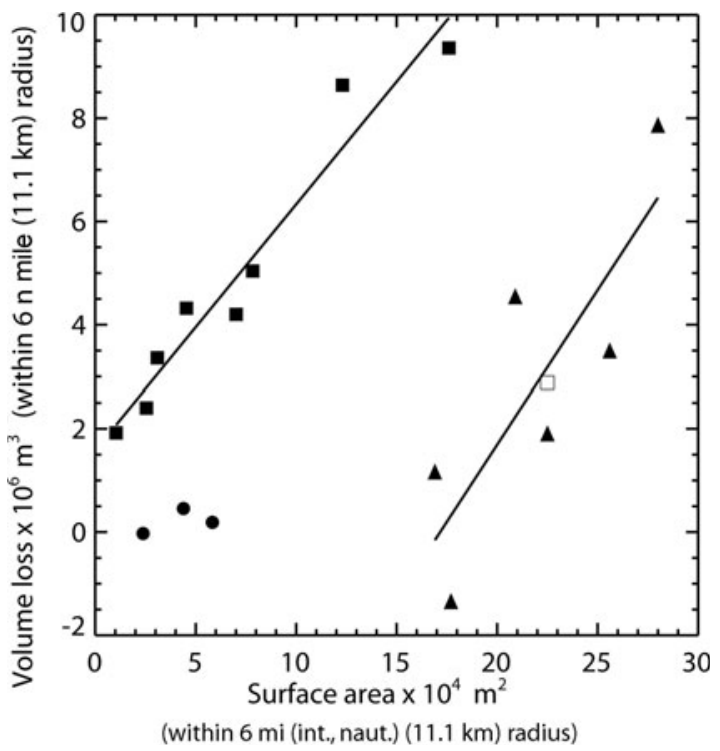

Fig. 10. Iceberg total volume loss (per $6 \mathrm{mi}$ (int., naut.) $(11.1 \mathrm{~km})$ observation radius) across $10^{\circ}$ longitude sectors, plotted as a function of total iceberg surface area below the ocean surface, $A_{\mathrm{w}}$, i.e. in contact with ocean water (in the same observation area). Full circles are the three points (i.e. across $3 \times 10^{\circ}$ sectors) pertaining to the iceberg size range, $25-100 \mathrm{~m}$; full triangles are points for the $100-200$ and $200-400 \mathrm{~m}$ size ranges. Squares (full and open) are for the 400-800, 800-1600 and 1600-3200 m size ranges. Straight lines are regression fits through the data represented by full squares $\left(r^{2}=0.94\right)$ and full triangles plus one open square $\left(r^{2}=0.68\right)$. 
area seems reasonable. Note that the mean temperature south of the Antarctic Divergence (in the $64-66^{\circ} \mathrm{S}$ bin) is $2^{\circ}$ lower than north of the Divergence.

\section{FRESHWATER INPUT TO THE OCEAN}

From the ice volume loss as the icebergs move through the study area, we can estimate the mass of freshwater input to the ocean. We need to assume mean iceberg density values for the different size categories; these are implied by the discussion above, of iceberg height to thickness ratio. For icebergs in the size category $>400 \mathrm{~m}$, we assume a height to thickness ratio (in sea water with density taken as $1030 \mathrm{~kg} \mathrm{~m}^{-3}$ ) of $1: 7$ (i.e. a mean iceberg density, $\rho=$ $\left.(6 / 7) \times 1030=883 \mathrm{~kg} \mathrm{~m}^{-3}\right)$. For icebergs in the $100-400 \mathrm{~m}$ size categories, we assume a height to thickness ratio of $1: 6\left(\rho=(5 / 6) \times 1030=858 \mathrm{~kg} \mathrm{~m}^{-3}\right)$ and for the smallest category, $<100 \mathrm{~m}$, a ratio of $1: 9 \quad(\rho=(8 / 9) \times 1030=$ $915 \mathrm{~kg} \mathrm{~m}^{-3}$ ).

In Table 4, the mass of freshwater input to the ocean per $11.1 \mathrm{~km}$ observation radius area is provided by multiplying the iceberg volume loss by the relevant mean iceberg density. Values in Table 4 are the freshwater input implied by the dataset, for each size category (and total across all size categories) per $10^{\circ}$ of longitude. The total freshwater contribution from iceberg dissolution as the icebergs traverse from $90-100$ to $100-110^{\circ} \mathrm{E}$ is $23.8 \mathrm{Mt}\left(2.38 \times 10^{10} \mathrm{~kg}\right)$ per $11.1 \mathrm{~km}$ observation radius (i.e. per $387 \mathrm{~km}^{2}$ ). The area of our study region between 90 and $100^{\circ} \mathrm{E}$ is $\sim 2.8 \times 10^{5} \mathrm{~km}^{2}$, and between 100 and $110^{\circ} \mathrm{E}$ is $\sim 2.4 \times 10^{5} \mathrm{~km}^{2}$. Since we are considering icebergs travelling from the first of these sectors to the second, we have assumed an ocean area of $2.6 \times 10^{5} \mathrm{~km}^{2}$ to estimate the total mass discharge, $M_{\mathrm{T}}$, within our latitudinal bands, per $10^{\circ}$ longitudinal sector as a result of iceberg dissolution to be

$$
M_{\mathrm{T}}=\frac{2.6 \times 10^{5}}{387} \times 23.8 \mathrm{Mt} \approx 1.60 \times 10^{4} \mathrm{Mt} \approx 16 \mathrm{Gt} .
$$

Similarly, for icebergs moving from $100-110$ to $110-120^{\circ} \mathrm{E}$ (mean $10^{\circ}$ sector area: $2.3 \times 10^{5} \mathrm{~km}^{2}$ )

$$
M_{\mathrm{T}}=\frac{2.3 \times 10^{5}}{387} \times 20.0 \mathrm{Mt} \approx 1.19 \times 10^{4} \mathrm{Mt} \approx 12 \mathrm{Gt},
$$

and for icebergs moving from $110-120$ to $120-130^{\circ} \mathrm{E}$ (mean area: $1.7 \times 10^{5} \mathrm{~km}^{2}$ )

$$
M_{\mathrm{T}}=\frac{1.7 \times 10^{5}}{387} \times 8.91 \mathrm{Mt} \approx 3.91 \times 10^{3} \mathrm{Mt} \approx 4 \mathrm{Gt} .
$$

To calculate the freshwater input on a time basis, we again need the estimates of drift rate (or residence time within each $10^{\circ}$ sector). The total freshwater contribution from iceberg dissolution between $90-100$ and $100-110^{\circ} \mathrm{E}$ is $2.38 \times 10^{10} \mathrm{~kg}$ per $11.1 \mathrm{~km}$ observation radius $\left(387 \mathrm{~km}^{2}\right)$. That is $61.5 \mathrm{~kg} \mathrm{~m}^{-2}$ or, assuming a residence time of 107 days for each $10^{\circ}$ longitude, $210 \mathrm{~kg} \mathrm{~m}^{-2} \mathrm{a}^{-1}$ (equivalent to precipitation of $21.0 \mathrm{~cm} \mathrm{a}^{-1}$ ). Between $100-110$ and $110-120^{\circ} \mathrm{E}$, the freshwater contribution is $176 \mathrm{~kg} \mathrm{~m}^{-2} \mathrm{a}^{-1}$ (equivalent to precipitation of $17.6 \mathrm{~cm} \mathrm{a}^{-1}$ ), and between $110-120$ and $120-130^{\circ} \mathrm{E}$ it is $78 \mathrm{~kg} \mathrm{~m}^{-2} \mathrm{a}^{-1}$ (equivalent to precipitation of $7.8 \mathrm{~cm} \mathrm{a}^{-1}$ ). Details for each size category are shown in Table 4. The above quantities are of the same order as those of Silva and others (2006) who estimate iceberg freshwater input around the whole continent, based on the NIC large iceberg dataset.

\section{COMPARISON WITH ANTARCTIC ICE SHEET OUTFLOW}

The amount of ice crossing the grounding zone of the Antarctic ice sheet amounts to $\sim 411 \mathrm{~km}^{3} \mathrm{a}^{-1}$ for East Antarctica and $\sim 429 \mathrm{~km}^{3} \mathrm{a}^{-1}$ for West Antarctica (Rignot and Thomas, 2002). Much of the snow accumulated on the continent, however, is deposited in the coastal area, downstream of the grounding zone including of course, the ice shelves. The Intergovernmental Panel on Climate Change (IPCC) estimate (Church and Gregory, 2001) of total accumulation (i.e. $P-E$, where $P$ is precipitation and $E$ is evaporation) over the Antarctic ice sheet is $2246 \pm 86 \mathrm{Gt} \mathrm{a}^{-1}$. Of this, the IPCC estimates $\sim 2072 \pm 304 \mathrm{Gta}^{-1}$ output by iceberg production. However, it has been realized since the IPCC report that as much as a third of the ice-sheet output may be accounted for by basal melt (Jacobs and others, 1996). Thus, we might expect $\sim 1500 \mathrm{Gta}^{-1}$ of the output to be from calving of icebergs.

On this basis, 2\% of the total Antarctic iceberg dissolution is accounted for within our $30^{\circ}$ longitude study sector. The Amery Ice Shelf (which drains $\sim 12 \%$ of East Antarctica) and the Shackleton Ice Shelf are the primary sources of icebergs into our study area. While $2 \%$ (distributed over $8 \%$ of the latitudinal extent of the coastline) is a smaller than expected fraction of the total (perhaps our observations and calculations have underestimated the total fraction), it needs to be noted that the Ross and Ronne-Filchner Ice Shelves discharge the greater proportion of the Antarctic ice into the Ross and Amundsen Seas and consequently around the Antarctic Peninsula into the Weddell Gyre, and the Weddell Sea area, on the opposite side of the Antarctic continent.

\section{CONCLUSIONS}

Several findings emerge from this study, concerning the distribution, movement, melt rates and freshwater input of icebergs in the Southern Ocean.

1. In the near-coastal regions, the distribution of icebergs is determined by the locations of the major ice outflow regions from the Antarctic ice sheet, and by the nearcoastal bathymetry, which causes icebergs to become grounded in shallow water.

2. In the deeper water away from the coast, the northern extent of Antarctic icebergs is remarkably similar to the northern extent of the maximum sea-ice extent, both being influenced by ocean temperature and current patterns in the area. The east-west distribution of icebergs is determined by the currents which are, in turn, influenced by the deep ocean bathymetry, and by the iceberg dissolution itself.

3. In the Circumpolar Current east of $90^{\circ} \mathrm{E}$, there is a decrease in iceberg concentration with increasing size category. Almost all the variability in the concentration is due to variability in the concentration of smaller icebergs.

4. Total iceberg volume is dominated by the larger icebergs. The effect on total iceberg volume of concentrations of icebergs $<200 \mathrm{~m}$ in linear dimension is very small, and it is the disintegration of the larger icebergs, primarily by breakage and subsequent melting as they drift towards the east, that accounts for most of the volume loss. 
5. The concentration and total volume of icebergs in our study area in 1984/85-1988/89 were higher (on average by a factor $>2$ ) than in the following two 5 year periods and (by a lesser amount) in the previous 6 year period. Volumes and concentrations were similar, however, in the $120-130^{\circ} \mathrm{E}$ sector and west of $80^{\circ} \mathrm{E}$. That is, the greater volume and concentration during the 1984/85$1988 / 89$ period occurred between 80 and $120^{\circ} \mathrm{E}$, the same area fed by the gyre operating northeast of Prydz Bay. These changes in concentration are not noted elsewhere around the Antarctic continent, and demonstrate the episodic nature of iceberg calving within local regions.

6. At temperatures $\sim 1^{\circ} \mathrm{C}$, iceberg dissolution rates, $\sim 0.03-$ $0.05 \mathrm{~m} \mathrm{~d}^{-1}$, are more than a factor of two lower than previously estimated; however, these calculations are highly dependent upon assumed drift speeds, which have the largest uncertainty.

7. The total mass contribution of fresh water to the ocean due to iceberg dissolution as they traverse the $30^{\circ}$ longitudinal sector studied is $\sim 32 \mathrm{Gt}$. This amounts to a contribution equivalent to precipitation of $\sim 15.5 \mathrm{~cm} \mathrm{a}^{-1}$. This total mass of ice melted within the $30^{\circ}$ sector study area accounts for $\sim 2 \%$ of the iceberg total discharged from the Antarctic ice sheet.

\section{FUTURE WORK}

The collection and statistical analysis of datasets as described here will continue to provide useful estimates of iceberg distributions and dissolution rates cheaply and conveniently. Programs such as the SCAR iceberg program are particularly valuable now that there is near-universal access to the data through the World Wide Web.

For a more accurate assessment of iceberg dissolution rates, however, and to better understand the processes of iceberg dissolution, we require studies that include repeat measurements on selected large icebergs. These projects need to be carried out over 1-5 years. Measurements are required of thickness (using ice thickness radar from the surface and, perhaps, upward-looking sonar from below), underwater side shape, i.e. depth profiles (using sidescanning sonar from ships), and width and length (using satellite remote-sensing techniques). That is, a full description of iceberg size is required. Recent techniques have been developed by US scientists (personal communication from T. Scambos, 2007) for measuring iceberg dissolution rates, by establishing self-reading ice radars on large icebergs. These radars are set up to measure the ice thickness once a day, and to transmit real-time data back to the laboratory. First fieldwork with this instrumentation was carried out during the 2006/07 austral summer Antarctic field season. Snow accumulation rate, ice temperature and horizontal ice strain rate on the iceberg surface, along with movement rate and meteorological (requiring placement of automatic weather stations (AWS) on the icebergs) and oceanographic data, will provide an indication of the iceberg dissolution rates and the dependence on weather and sea conditions.

Several icebergs should be examined, including a selection in the coastal region (i.e. in the east wind drift regime with low in situ water temperature) and a selection of more northerly icebergs (that have moved into the Circumpolar
Current with relatively higher water temperatures). For each iceberg, a sequence of at least two (and preferably three to five) sets of measurements over the 5 year period of the project should be made. A project such as outlined above has been proposed for the AAP, and some preliminary work, including placement of an AWS, has been carried out on the B9B iceberg in East Antarctica. It is expected that further fieldwork will be carried out within the next few years.

For the longer term, however, more accurate satellitebased sensing of icebergs from the current and future generation of remote-sensing instrumentation (e.g. Scambos and others, 2005) will provide the best estimates of iceberg dissolution rates. Even these measurements, though, need high-quality 'ground-truth' measurements, such as provided by the ship-based observations.

\section{ACKNOWLEDGEMENTS}

We thank all the Australian Antarctic expedition personnel (including scientists, support personnel and ship's officers and crew) on voyages south who have contributed to the iceberg observation program. Without their support and enthusiasm, this project could not succeed, the data on the website would not exist and the results published in this paper would not be possible. We thank N. Bindoff and C. Domingues for providing the previously unpublished oceanographic data in Table 2. T. van Ommen and W. Budd (who suggested the volume calculations) provided reviews which have led to several important improvements. For this paper, M. Lange acted as Chief Scientific Editor. He along with $\mathrm{O}$. Orheim and an anonymous reviewer are thanked for several very helpful comments. This work was supported in part by the Australian Government's Cooperative Research Centres programme through the Antarctic Climate and Ecosystems Cooperative Research Centre (ACE CRC).

\section{REFERENCES}

Allison, I. and G. Musil. 1989. Abstract: seasonal changes in iceberg distribution off East Antarctica. Ann. Glaciol., 12, 211.

Bindoff, N.L., M.A. Rosenberg and M.J. Warner. 2000. On the circulation and water-masses over the Antarctic continental slope and rise between 80 and $150^{\circ}$ E. Deep-Sea Res. II, 47(1213), 2299-2326.

Budd, W.F. 1986. The Southern Hemisphere circulation of atmosphere ocean and sea ice. In Second International Conference on Southern Hemisphere Meteorology, December 1-5, 1986, Wellington, New Zealand. Proceedings. Boston, MA, American Meteorological Society, 101-106.

Budd, W.F., T.H. Jacka and V.I. Morgan. 1980. Antarctic iceberg melt rates derived from size distributions and movement rates. Ann. Glaciol., 1, 103-112.

Church, J.A. and 7 others. 2001. Changes in sea level. In Houghton, J.T. and 7 others, eds. Climate change 2001: the scientific basis. Contribution of Working Group I to the Third Assessment Report of the Intergovernmental Panel on Climate Change. Cambridge, etc. Cambridge University Press, 639-693.

Crepon, M., M.N. Houssais and B. Saint Guily. 1988. The drift of icebergs under wind action. J. Geophys. Res., 93(C4), 3608-3612.

Dmitrash, Z.A. 1971. O nekotorykh osobennostyakh raspredeleniya aysbergov $v$ Vostochnoy Antarktike [Some characteristics of iceberg distribution in the Eastern Antarctic]. Sov. Antarct. Exped. Inf. Bull., 82, 37-41. 
Fricker, H.A., N.W. Young, I. Allison and R. Coleman. 2002. Iceberg calving from the Amery Ice Shelf, East Antarctica. Ann. Glaciol., 34, 241-246.

Hamley, T.C. and W.F. Budd. 1986. Antarctic iceberg distribution and dissolution. J. Glaciol., 32(111), 242-251.

Heil, P. and I. Allison. 1999. The pattern and variability of Antarctic sea-ice drift in the Indian Ocean and western Pacific sector. J. Geophys. Res., 104(C7), 15,789-15,802.

Hemming, S.R. 2004. Heinrich events: massive late Pleistocene detritus layers of the North Atlantic and their global climate imprint. Rev. Geophys., 42(1), RG1005. (10.1029/ 2003RG000128.)

Hofmann, E.E. 1985. The large-scale horizontal structure of the Antarctic circumpolar current from FGGE drifters. J. Geophys. Res., $90(C 4), 7087-7097$.

Husseiny, A.A., ed. 1978. Iceberg utilization: Proceedings of the First International Conference and Workshops on Iceberg Utilization for Fresh Water Production, Weather Modification and Other Applications, Ames, lowa, USA, 26 October 1977. Elmsford, NY, Pergamon Press.

Jacka, T.H. 1983. A computer data base for Antarctic sea ice extent. ANARE Res. Notes 13.

Jacobs, S.S., H.H. Hellmer and A. Jenkins. 1996. Antarctic ice sheet melting in the southeast Pacific. Geophys. Res. Lett., 23(9), 957-960.

Lawson, J.D. and D.S. Russell-Head. 1983. Augmentation of urban water by Antarctic icebergs. In Edge, B.L., ed. Proceedings of the Eighteenth Coastal Engineering Conference, Cape Town, South Africa, November 14-19, 1982. New York, American Society of Civil Engineers.

Lazzara, M.A., K.C. Jezek, T.A. Scambos, D.R. MacAyeal and C.J. van der Veen. 1999. On the recent calving of icebergs from the Ross Ice Shelf. Polar Geogr., 23(3), 201-212.

Long, D.G., J. Ballantyne and C. Bertoia. 2002. Is the number of Antarctic icebergs really increasing? Eos Trans., AGU, 83(42), 469.

Musil, G. 1990. On iceberg observations using the ship's radar. Iceberg Res. 15, 28-34.

Neshyba, S. and E.G. Josberger. 1980. On the estimation of Antarctic iceberg melt rate. J. Phys. Oceanogr., 10(10), 1681-1685.

Orheim, O. 1980. Physical characteristics and life expectancy of tabular Antarctic icebergs. Ann. Glaciol., 1, 11-18.

Orheim, O. 1985. Iceberg discharge and the mass balance of Antarctica. In Polar Research Board, ed. Glaciers, ice sheets, and sea level: effect of a $\mathrm{CO}_{2}$ induced climatic change. Report of a Workshop held in Seattle, Washington, September 13-15, 1984. Washington, DC, US Department of Energy, 210-215. (Report DOE/ER/60235-1.)

Rignot, E. 2001. Evidence for rapid retreat and mass loss of Thwaites Glacier, West Antarctica. J. Glaciol., 47(157), 213-222.

Rignot, E. and R.H. Thomas. 2002. Mass balance of polar ice sheets. Science, 297(5586), 1502-1506.

Robe, R.Q. 1980. Iceberg drift and deterioration. In Colbeck, S.C., ed. Dynamics of snow and ice masses. New York, Academic Press, 211-259.
Rott, H., P. Skvarca and T. Nagler. 1996. Rapid collapse of northern Larsen Ice Shelf, Antarctica. Science, 271(5250), 788-792.

Rott, H., W. Rack, T. Nagler and P. Skvarca. 1998. Climatically induced retreat and collapse of northern Larsen Ice Shelf, Antarctic Peninsula. Ann. Glaciol., 27, 86-92.

Rott, H., W. Rack, P. Skvarca and H. De Angelis. 2002. Northern Larsen Ice Shelf, Antarctica: further retreat after collapse. Ann. Glaciol., 34, 277-282.

Row, L.W. and D.A. Hastings. 1995. TerrainBase worldwide digital terrain data on $C D-R O M$, release 1.0. Boulder, CO, National Oceanic and Atmospheric Administration. National Geophysical Data Center.

Row, L.W., D.A. Hastings and P.K. Dunbar. 1995. TerrainBase worldwide digital terrain data - documentation manual, $C D$ ROM, release 1.0. Boulder, CO, National Oceanic and Atmospheric Administration. National Geophysical Data Center.

Russell, W.E., ed. 1979. Iceberg dynamics symposium, June 4 and 5, 1979, St John's, Newfoundland, Canada. Cold Reg. Sci. Technol., 1(3-4), 167-306.

Russell-Head, D.S. 1980. The melting of free-drifting icebergs. Ann. Glaciol., 1, 119-122.

Scambos, T., O. Sergienko, A. Sargent, D. MacAyeal and J. Fastook. 2005. ICESat profiles of tabular iceberg margins and iceberg breakup at low latitudes. Geophys. Res. Lett., 32(23), L23S09. (10.1029/2005GL023802.)

Schwerdtfeger, P. 1979. On icebergs and their uses: a report to the Australian Academy of Science. Cold Reg. Sci. Technol., 1(1), 59-79.

Shabtaie, S. and C.R. Bentley. 1982. Tabular icebergs: implications from geophysical studies of ice shelves. J. Glaciol., 28(100), 413-430.

Silva, T.A.M., G.R. Bigg and K.W. Nicholls. 2006. Contribution of giant icebergs to the Southern Ocean freshwater flux. J. Geophys. Res., 111(C3), C03004. (10.1029/2004JC002843.)

Tchernia, P. and P.F. Jeannin. 1984. Circulation in Antarctic waters as revealed by iceberg tracks, 1972-1983. Polar Rec., 22(138), 263-269.

Wadhams, P. 1988. Winter observations of iceberg frequencies and sizes in the South Atlantic Ocean. J. Geophys. Res., 93(C4), 3583-3590.

Weeks, W.F. and W.J. Campbell. 1973. Icebergs as a fresh-water source: an appraisal. J. Glaciol., 12(65), 207-233.

Wingham, D.J., A.L. Ridout, R. Scharroo, R.J. Arthern and C.K. Shum. 1998. Antarctic elevation change from 1992 to 1996. Science, 282(5388), 456-458.

Young, N.W. 1998. Antarctic iceberg drift and ocean currents derived from scatterometer image series. In Proceedings of a Joint ESA-EUMETSAT Workshop on Emerging Scatterometer Applications From Research to Operations. Noordwijk, European Space Agency, 125-132. (ESA Special Publication SP-424.)

Young, N.W., D. Turner, G. Hyland and R.N. Williams. 1998. Nearcoastal iceberg distributions in East Antarctica, 50-145 ${ }^{\circ}$ E. Ann. Glaciol., 27, 68-74.

Zwally, H.J. and 15 others. 2002. ICESat's laser measurements of polar ice, atmosphere, ocean and land. J. Geodyn., 34(3-4), 405-445. 